\title{
REVIEW
}

\section{Mapping genetic alterations causing chemoresistance in cancer: identifying the roads by tracking the drivers}

PE Lønning ${ }^{1,2}$ and S Knappskog ${ }^{1,2}$

\begin{abstract}
Although new agents are implemented to cancer therapy, we lack fundamental understandings of the mechanisms of chemoresistance, the main obstacle to cure in cancer. Here we review clinical evidence linking molecular defects to drug resistance across different tumour forms and discuss contemporary experimental evidence exploring these mechanisms. Although evidence, in general, is sparse and fragmentary, merging knowledge links drug resistance, and also sensitivity, to defects in functional pathways having a key role in cell growth arrest or death and DNA repair. As these pathways may act in concert, there is a need to explore multiple mechanisms in parallel. Taking advantage of massive parallel sequencing and other novel high-throughput technologies and base research on biological hypotheses, we now have the possibility to characterize functional defects related to these key pathways and to design a new generation of studies identifying the mechanisms controlling resistance to different treatment regimens in different tumour forms.
\end{abstract}

Oncogene (2013) 32, 5315-5330; doi:10.1038/onc.2013.48; published online 11 March 2013

Keywords: chemoresistance; TP53; DNA repair; mutations; germline; chemotherapy

\section{INTRODUCTION}

Chemoresistance remains the main obstacle to cancer cure. Despite a titanic number of experimental studies, the number of clinical therapy studies focusing on the mechanisms of resistance is small and, in general, include a small number of patients each. Here we will review and discuss contemporary findings related to chemoresistance in vivo. Considering the individual mechanisms, their impact on drug sensitivity has been described for a limited number of drug regimens in few types of cancer only; the best examples being the impact of disturbances in homologous end repair on platinum and anthracycline compound sensitivity in breast and ovarian cancer, and the effects of TP53 mutations in breast cancer and haematological malignancies. As for experimental in vitro evidence, a comprehensive review of experimental research related to chemoresistance is beyond the scope of this paper. Instead, we include experimental evidence of relevance to the in vivo findings.

Although some factors, such as expression of the metalloproteinase TIMP-1, has been correlated with resistance to some combination regimens $s^{1,2}$ and expression of the $\tau$-protein has been related to resistance to taxanes, ${ }^{3}$ most of the gene cascades associated with chemoresistance identified relates to gene pathways involved in apoptosis/senescence and DNA repair. Considering factors like human epidermal growth factor receptor 2 (HER-2) and/or topoisomerase-II (Topo-II) amplifications, these parameters do not predict drug resistance; rather, they advocate a 'dose-dependent sensitivity' to anthracyclines. As for the growth factor/protein kinase pathways, such as the phosphatase and tensin homologue/phosphoinositide 3-kinase/mammalian target of rapamycin (PTEN/PI3K/mTOR) pathway, these factors have a role in resistance to endocrine therapy in breast cancer, but their role in resistance to chemotherapy remains to be addressed. Further, components of the PTEN/PI3K/mTOR pathway also influence p53 function and interacts with DNA repair mechanisms. In contrast, merging evidence links key pathways regulating apoptosis/senescence and DNA repair to chemoresistance. Notably, most cancer susceptibility genes are involved in these pathways as well. Thus, we will re-examine the previously proposed hypothesis that genes involved in hereditary cancer syndromes may act as 'beacons', identifying key mechanisms regulating drug resistance in vivo. ${ }^{4}$

\section{MODELLING DRUG RESISTANCE IN VIVO, DEFINING PROGNOSTIC AND PREDICTIVE FACTORS}

The issue of prognostic versus predictive factor have been reviewed by the authors in detail elsewhere; ${ }^{5,6}$ only a brief summary will be presented here. A prognostic factor may be any tumour characteristic associated with either relapse-free or overall survival subsequent to local treatment (surgery and/or radiotherapy) for a primary cancer (Figure 1a). In contrast, a predictive factor is a parameter associated with response to a particular anti-tumour agent.

There are three general models for studying predictive factors. The first model (Figure 1a) takes advantage of adjuvant therapy trials. Examples of such studies are the seminal trials establishing the predictive role of the oestrogen receptor in anti-hormonal therapy, comparing receptor expression with outcome in patients randomized to either anti-oestrogen tamoxifen or no adjuvant therapy after primary surgery. ${ }^{7}$ Currently, such trials may compare treatment with a less extensive ('regimen $A^{\prime}$ ) versus more extensive ('regimen $A+$ drug $B^{\prime}$ ) regimen.

The second model (Figure $1 \mathrm{~b}$ ) involves studying anti-tumour response by measuring alterations in tumour size in response to defined therapeutic regimens. ${ }^{5}$ Although this model may be

\footnotetext{
${ }^{1}$ Section of Oncology, Institute of Medicine, University of Bergen, Bergen, Norway and 2Department of Oncology, Haukeland University Hospital, Bergen, Norway. Correspondence: Professor PE Lønning, Department of Oncology, Haukeland University Hospital, Jonas Lies vei 65, Bergen, Hordaland N-5021, Norway.

E-mail: per.lonning@helse-bergen.no
}

Received 29 November 2012; revised 16 January 2013; accepted 16 January 2013; published online 11 March 2013 


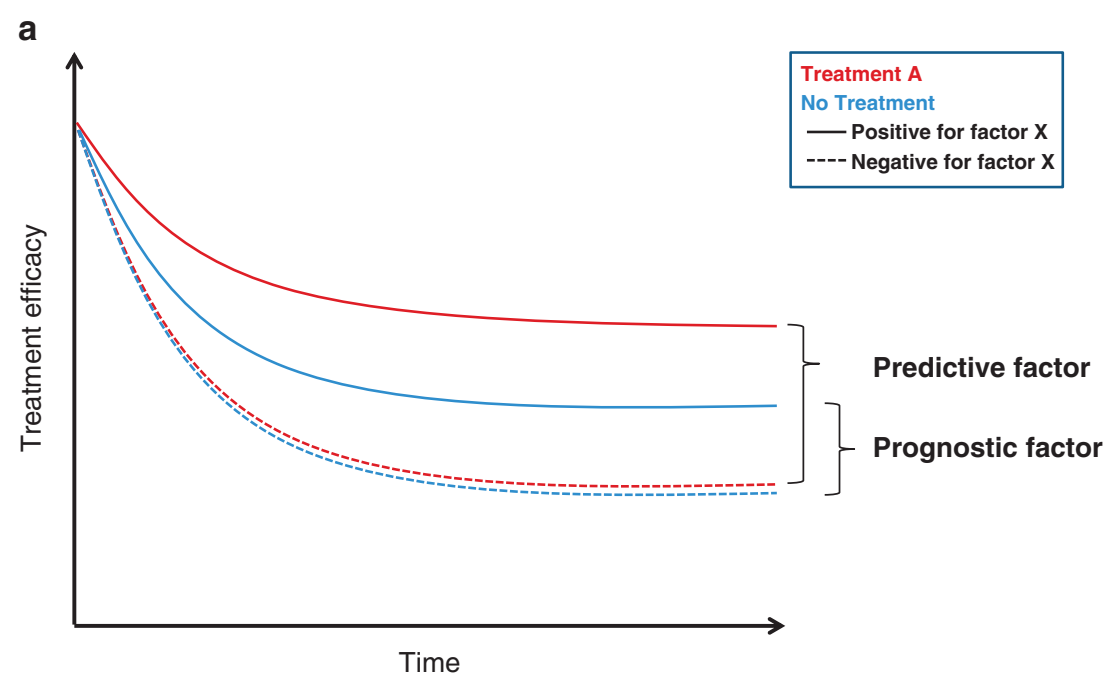

b

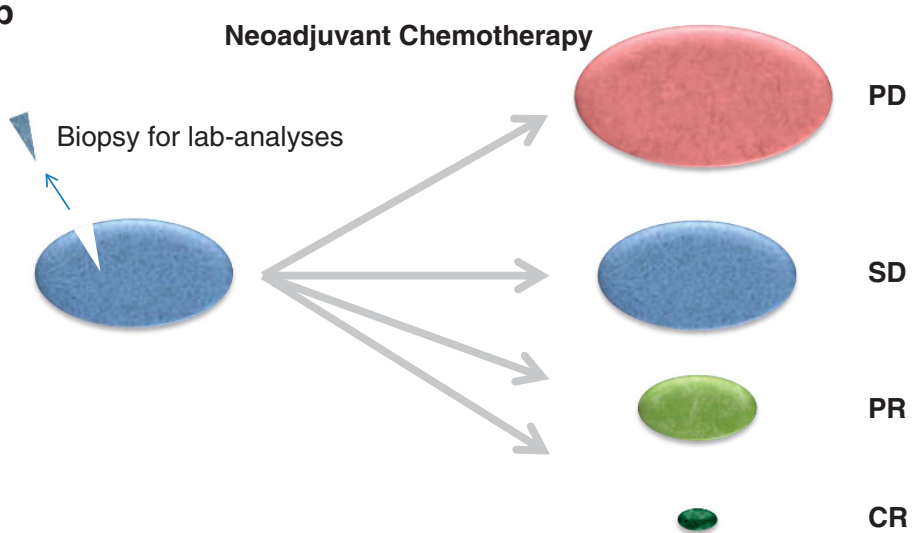

Tumour before therapy

C
Tumour after therapy
PD

D

PR

CR

\section{Chemosensitive tumour cell}

Chemoresistant tumour cell

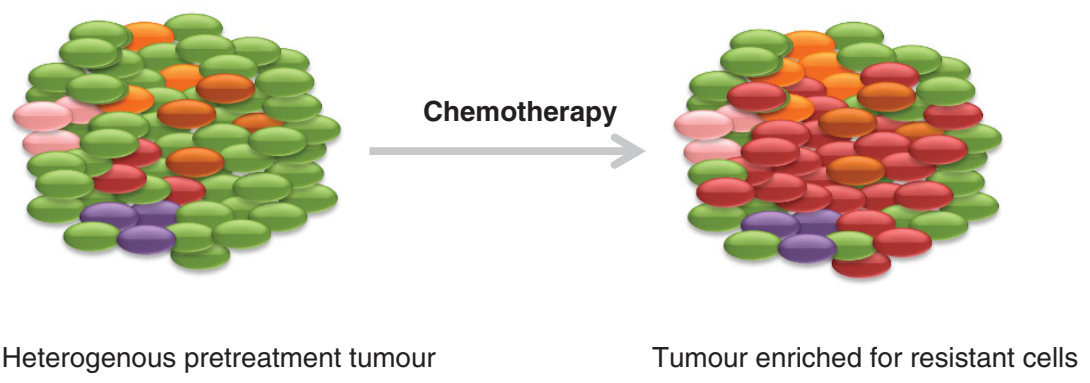

Figure 1. Strategies for assessing predictive value of a biomarker. (a) Comparison of outcome in patients positive or negative for a biomarker (factor X), with or without treatment or receiving different treatment regimens, (b) comparison of biomarkers in resistant versus sensitive tumours, (c) comparison of the fraction of cells harbouring a biomarker in post-treatment samples (enriched for resistant cells) with the corresponding fraction in pre-treatment samples.

applied in metastatic disease, over the last two decades it has been more widely adopted in pre-surgical, or so-called 'neoadjuvant', treatment for primary cancers. Whereas tumours increasing in size on therapy contain a substantial amount of therapy-resistant cells, tumours obtaining a so-called 'complete pathological response' to chemotherapy contain cells sensitive to therapy. The fact that a complete pathological response in response to primary chemotherapy correlates to long-term survival in breast cancers ${ }^{8}$ indicates complete pathological response to be associated with eradication of micrometastases as well.

A third possibility is to analyse repeated samples before and after therapy, and assess elimination versus enrichment of certain cell clones harbouring distinct defects. This may link specific gene 
mutations to chemosensitivity or resistance (Figure 1c). Implementing massive parallel sequencing ('next generation sequencing') will greatly increase the feasibility of this strategy, as the percentage of sequence reads harbouring a mutation (thus, reflecting the percentage of mutated cells) from any sample can be easily calculated (Figure 2 ).

Needless to say, prognostic as well as predictive factors are, by definition, statistical correlates; the fact that individual factors may be covariates warns for caution linking such factors to tumour biology.

\section{TP53}

No single gene has been more extensively studied than TP53, the gene coding for the $\mathrm{p} 53$ protein. Thus, the search item ' $\mathrm{p} 53^{\prime}$ provides $>78000$ hits in the ISI Web of knowledge database (January 2013), a figure 10-fold the numbers for HER-2 and erbB-2 combined, and nearly 20-fold the number for BRAF.

Germline TP53 mutations are associated with the classical $\mathrm{Li}-$ Fraumeni syndrome (LF) and the more lately defined 'LF-like' syndrome, the latter characterized by somewhat less stringent criteria. ${ }^{9}$ Both syndromes are associated with enhanced risk of multiple malignant diseases at early age; the most characterized being different types of sarcomas. p53 contains a frequent arginine/proline polymorphism in codon 72. Although Arg72 has been shown to be more effective in inducing apoptosis compared with Pro $72,{ }^{10}$ contemporary evidence from experimental studies do not indicate a significant effect of this variant on chemosensitivity, and a recent meta-analysis found no effect on cancer risk. ${ }^{11}$

When evaluating TP53 mutation function in vivo, there is a need to emphasize on proper detection methods. Because of the fact that many p53 protein variants harbouring missense mutations are slowly degraded, causing a protein detectable by immunostaining, p53 staining is widely used as a surrogate marker for TP53 mutation status. However, we ${ }^{12}$ and others ${ }^{13}$ have shown that about $30 \%$ of TP53 mutations are not associated with immunostaining in breast cancers. Moreover, such lack-ofstaining relates, in particular, to truncating non-sense mutations that, in general, are associated with complete loss of protein function. For this reason, papers evaluating p53 status only by immunostaining are not examined in this review.

Although direct application of p53 through retroviral vectors have achieved tumour regression in lung cancers, ${ }^{14}$ such trials were terminated due to poor systemic delivery. The first trials ${ }^{15}$ exploring compounds that restore p53 function in tumours harbouring mutations that cause conformational changes of the p53 protein ${ }^{16,17}$ have been undertaken. Although this is an interesting approach, such strategies are unlikely to work in tumours harbouring non-sense TP53 mutations.

TP53 mutations have been associated with chemoresistance in different haematological malignancies such as chronic lymphocytic leukemia, T-cell leukemia, acute lymphoblastic leukemia, Burkitt's lymphoma and acute myeloid leukemia, as well as in aggressive B-cell lymphoma. The regimens to which TP53 mutations predicted drug resistance included treatment with purine (pentostatin) or pyrimidine (fludarabine) analogues, as well as combination regimens containing anthracycline, cyclophosphamide, cytosine arabinoside, vincristine and/or etoposide. ${ }^{18-23}$ Considering primary (pre-surgical) treatment of breast cancer, TP53 mutations have been associated with anthracycline and mitomycin resistance, ${ }^{12,24-26}$ but not with taxane resistance, ${ }^{26,27}$ similarly, one study evaluating efficacy of taxanes in the adjuvant setting ${ }^{28}$ and two studies evaluating anthracyclines and taxanes administered in concert, or sequentially, found no effect of TP53 mutation status on response. ${ }^{29,30}$

Yet, there is evidence at variance. Thus, de The and colleagues ${ }^{31}$ found TP53 mutations to predict improved response to chemotherapy in breast cancer; this effect, however, was observed among patients receiving cyclophosphamide at high doses in concert with anthracyclines. In a recent experimental study, Song et al. ${ }^{32}$ provided interesting evidence potentially explaining this finding. $\mathrm{N}$-methylpurine DNA glycosylase, known to be expressed in breast cancer, triggers DNA strand breaks in response to alkylating agents by increasing abasic sites. Although these lesions induced p53-dependent growth arrest and were effectively repaired in p53-proficient cells, they were repaired at poor efficiency in cells mutated for TP53, subsequently leading to cell death. 
Bonnefoi et al. ${ }^{33}$ explored the predictive value of TP53 status in a group of 1856 patients randomized to primary medical treatment with either 5-fluorouracil, epirubicin and cyclophosphamide or combined treatment with docetaxel and epirubicin. TP53 mutations did not predict either direct therapy response or progression-free survival in any of the two arms. Of note, in this study, TP53 mutation status was assessed using a yeast assay, and the frequency of tumours classified as TP53mutated (44\%) exceeded the corresponding frequency usually detected in breast cancer (20-30\%). Importantly, a fraction of patients enroled in the '5-fluorouracil, epirubicin and cyclophosphamide' arm did not have a conventional regimen but received cyclophosphamide at high doses. Thus, the fact that most patients in this study received either taxotere or cyclophosphamide at high doses may have contributed significantly to the result.

Regarding other cancer forms, TP53 mutations was found to predict a better response to combined platinum-taxane therapy but not to platinum monotherapy in ovarian cancer patients. ${ }^{34,35}$ Interestingly, TP53 mutations have been found to be associated with resistance to cisplatin combined with etoposide ${ }^{36}$ in nonsmall cell lung cancer as well as to cisplatin combined with ifosfamide. ${ }^{37}$ The results from the former study ${ }^{36}$ may be consistent with the observations regarding anthracyclines in as much as etoposide, being a Topo-II inhibitor, resembles the anthracyclines with respect to mechanism of action. Ifosfamide, on the contrary, is metabolized into cyclophosphamide in vivo. The findings from the second study may be inconsistent with the results from the study by de The and colleagues, ${ }^{31}$ but notably the de The study applied cyclofosfamide as a 'high-dose' regimen of $1200 \mathrm{mg} / \mathrm{m}^{2}$ every second week (contrasting a regular dose of cyclophosphamide $600 \mathrm{mg} / \mathrm{m}^{2}$ every third week in breast cancer). Further, these results ${ }^{37}$ may have been influenced by administration of cisplatin in concert.

Although p53 is involved in multiple cellular processes, including growth arrest, DNA damage repair, apoptosis, senescence $^{38}$ and, by more recent evidence, also necrosis and autophagy, ${ }^{39,40}$ we have no clear understanding of which process is responsible for tumour suppression or chemotoxic cell death. In addition to apoptosis, experimental evidence has favoured senescence as a p53-induced anti-tumour response, ${ }^{41}$ whereas others, ${ }^{42}$ using different models, reported p53-induced senescence to hamper DNA response by blocking apoptosis. Although this phenomenon occurred only in mutant tumours with concomitant loss of the normal p53 allele (loss of heterozygosity), notably loss of heterozygosity does in fact occur in most human breast cancers harbouring TP53 mutations. ${ }^{12,24}$

p53 is not primarily activated by transcriptional upregulation but by post-translational events, including phosphorylations, acetylations, sumoylations and monoubiquitinations. ${ }^{38}$ Phosphorylation occurs at multiple sites; although experimental evidence indicate phosphorylations at serine 15 and 20 by the ataxia telangiectasia mutated (ATM) and chk2 kinases to have a critical role in response to DNA damage, phosphorylation at serine 46 , which is caused by other kinases, seems of major importance in the execution of apoptosis. ${ }^{4-45}$ The mechanisms deciding between growth arrest versus apoptosis is incompletely understood, but there seems to be structural differences in the promoters of genes responding rapidly (like the CDKN1A coding for p21) as compared with the more slowly acting genes involved in apoptosis, ${ }^{46,47}$ and integrated models for a time sequence involving protein phosphorylations and promoter activation has been proposed. ${ }^{48}$ Drug doses may have influenced outcome as well; thus, multiple kinase inhibition by low doses of reversine were shown to induce apoptosis in a p53-dependent manner. In contrast, elevated doses caused abortive mitosis leading to mitotic catastrophy and apoptosis in p53-deficient cells. ${ }^{49}$ In addition, some mutants reveal gain-of-function ${ }^{50}$ and some mutants, such as codon 175 mutations, are involved in DNA binding, but induces conformational changes as well. ${ }^{51}$ Finally, p53 may induce apoptosis in a non-transcriptional way through direct binding to components of the bcl-2 system, such as bax. ${ }^{52}$ The fact that chemoresistance in vivo has been associated with TP53 mutations affecting the DNA-binding loop 2 (L2) and loop 3 (L3) domains do not exclude that transcription-independent apoptosis could have a critical role in drug response in as much as the L3 domain, in particular, has been linked to transcription-independent apoptosis in addition to DNA binding. ${ }^{53}$

Notably, multiple TP53 splice variants have been discovered ${ }^{54}$ and several of these have been shown to modulate full-length TP53 transcription in vitro. Although the biological effects of the splice variants in vivo remains to be fully elucidated, interestingly, expression of an isoform lacking codon 257-322 did not affect metastatic propensity neither in wild-type tumours nor in tumours harbouring TP53 mutations; ${ }^{55}$ in contrast, p53 $\gamma$, lacking part of the C-domain, was shown to neutralize the negative prognostic effect of TP53 mutations. ${ }^{56}$ Thus, it should be of interest to learn whether this variant (and potentially, others), may influence chemosensitivity as well.

Interestingly, recent experimental evidence in mice has questioned whether the mechanisms of tumour suppression and tumour DNA damage response may differ. Thus, Li et al. $^{57}$ and Brady et $a l^{58}$ reported tumour suppression with TP53 mutants defective in causing cell cycle arrest, apoptosis, as well as senescence in response to DNA damage. Regarding chemoresistance in vivo, the predictive value of somatic TP53 mutations with respect to anthracycline/mitomycin resistance does not seem to differ between TP53 mutations exclusively observed as somatic and those mutations that have been detected as germline mutations in LF/LF-like families as well (Table 1).

\section{OTHER GENES INVOLVED IN THE P53 PATHWAY}

ATM phosphorylates p53 at serine 15 and chk2 at threonine 68 in response to DNA damage. Subsequently, chk2 phosphorylates p53 at serine 20 , preventing MDM2 protein binding. Although chk2 also phosphorylates p53 at six additional sites, including serine 313 and 314 located in the nuclear localization signal, ${ }^{38}$ the role of these phosphorylations in p53 activation remains poorly understood. The ATM/chk2 pathway is considered a major mechanism of p53 activation in response to DNA damage, although some reports suggest ATM as well as chk2 to be redundant to this function. ${ }^{60-62}$

Although evidence linking heterozygous ATM mutations to breast cancer risk is at variance, ${ }^{63}$ a moderately elevated risk has been associated with heterozygous mutations located in certain protein domains. ${ }^{64}$ Ataxia telangiectasia, however, is a recessive disorder; thus, individuals carrying biallelic ATM mutations in addition are at significant elevated risk of multiple cancer forms. ${ }^{65}$ Interestingly, recent evidence indicate cancer risk to be particularly elevated among individuals carrying 'null' mutations, that is, mutations associated with lack of ATM protein expression, ${ }^{66}$ an interesting parallel to our finding that low ATM expression levels, but not heterozygous mutations, ${ }^{67}$ was associated with drug resistance (see details below).

Following an initial report of a CHEK2 germline mutation in a family diagnosed with the LF syndrome, ${ }^{68}$ subsequent studies detected a BRCA2 mutation in the same family, and BRCA2 mutations are now considered the cause of several cases of LF/LF-like families. ${ }^{69}$ However, truncating (but not missense) CHEK2 mutations, the most common being the del1100C variant detected in $0.5-1 \%$ of north-eastern Europeans, are associated with a 2- to 3-fold elevated risk of breast cancer, ${ }^{70,71}$ as well as other tumour forms, such as cancers of the thyroid and prostate. 
Table 1. TP53 mutations observed in three series of breast cancer patients

(a) TP53 mutations observed in three series of breast cancer patients $(9,21,22)$ with defined in vivo response to neoadjuvant anthracycline or mitomycin treatment (total $n=176)^{a}$

\begin{tabular}{|c|c|c|}
\hline Mutation & Amino acid change & $\begin{array}{l}\text { Response }^{\mathrm{b}} \\
\text { (number of pats) }\end{array}$ \\
\hline \multicolumn{3}{|c|}{ Mutations linked to $L F S / L F L^{c}$} \\
\hline A488G & Y163C & $\mathrm{PR}^{2}$ \\
\hline C406T & Q136X & PR \\
\hline G524A & $\mathrm{R} 175 \mathrm{H}$ & $\mathrm{PD}, \mathrm{SD}^{2} \mathrm{PR}^{2} \mathrm{CR}$ \\
\hline C637T & R213X & PD, PR \\
\hline A659G & Y220C & SD, PR \\
\hline G730A & G244S & $P D, P R$ \\
\hline G731A & G244D & SD \\
\hline G733T & G245C & ND \\
\hline G743A & R248Q & PD \\
\hline G818A & $\mathrm{R} 273 \mathrm{H}$ & PR \\
\hline C844T & $\mathrm{R} 282 \mathrm{~W}$ & SD \\
\hline G892T & E298X & PR \\
\hline \multicolumn{3}{|c|}{ Mutations previously observed as somatic mutations in breast cancer ${ }^{c}$} \\
\hline T319G & Y107D & PR \\
\hline del exon 5 & Frameshift at 125 & PD, SD \\
\hline C380T & S127F & SD \\
\hline G404A & C135Y & PR \\
\hline del 3 bp & del 160 & PD \\
\hline C493T & Q165X & PR \\
\hline A503C & $\mathrm{H} 168 \mathrm{P}$ & SD \\
\hline G527T & $\mathrm{C} 176 \mathrm{~F}$ & SD \\
\hline C569T & P190L & SD \\
\hline A578T & H193L & PR \\
\hline T581G & L194R & PR \\
\hline T584C & I195T & $P D, P R$ \\
\hline G610T & E204X & PD \\
\hline T613G & Y205D & SD \\
\hline G711T & M237I & PR \\
\hline A745G & R249G & PD \\
\hline A763T & $1255 \mathrm{~F}$ & PR \\
\hline G818C & R273P & SD \\
\hline G973T & G325X & PD \\
\hline G1010T & R337L & PR \\
\hline \multicolumn{3}{|l|}{ Novel mutations } \\
\hline $\mathrm{G}>\mathrm{C}$ exon $9+1$ & Splice error, Frameshift at 332 & SD \\
\hline 18 bp del & Frameshift at 25 & SD \\
\hline 22 bp del & Frameshift at 46 & PD \\
\hline ins $1 \mathrm{bp}$ & Frameshift at 73 & PD \\
\hline del exon 6 & Frameshift at 186 & PD \\
\hline del 14 bp & Frameshift at 217 & PD \\
\hline del $6 \mathrm{bp}$ & del232-234 & SD \\
\hline del $11 \mathrm{bp}$ & Frameshift at 239 & PR \\
\hline G744A & R248R & PR \\
\hline ins $12 \mathrm{bp}$ & In frame at 256 & SD \\
\hline
\end{tabular}

(b) Association between TP53 mutations and response to chemotherapy. Pooled data from $(9,21,22$; total $n=176 ; P=0.0020)$

\begin{tabular}{|lcc|}
\hline & $P D^{\mathrm{b}}$ & Response $^{\mathrm{b}}(C R+P R+S D)$ \\
\hline TP53-mutated & 17 & 43 \\
TP53 wild-type & 11 & 105 \\
\hline
\end{tabular}

(c) Association between TP53 mutations (L2/L3) and response to chemotherapy. Pooled data from $\left(9,21,22 ;\right.$ total $\left.n=176 ; P=9.11 \times 10^{-5}\right)$

\begin{tabular}{|lcc|}
\hline & $P D^{\mathrm{b}}$ & Response $^{\mathrm{b}}(C R+P R+S D)$ \\
\hline TP53-mutated & 15 & 25 \\
TP53 wild-type & 13 & 123 \\
\hline
\end{tabular}

Abbreviations: LF, Li-Fraumeni; LFL, LF-like; PD, progressive disease; $P R$, partial response; $\mathrm{SD}$, stable disease; $\mathrm{CR}$, complete response. ${ }^{\text {a Note }}$ that several of the missense mutations associated with chemoresistance (PD) have also been detected as germline mutations in families diagnosed with the LF or the LFL syndrome. ${ }^{b}$ According to the IARC TP53 database (wwwp53.iarc.fr), release R15. 'Response to therapy defined as PD, SD, PR or CR.

Although several studies correlated TP53 mutations to therapy failure in breast cancer, the same studies ${ }^{12,24,25}$ reported tumours failing on therapy harbouring wild-type TP53 and tumours responding to treatment despite harbouring TP53 mutations known to impair p53 protein function (Table 1). One explanation as to why tumours harbouring wild-type TP53 are resistant to therapy could be defects involving other components of the 'p53 pathway'. Thus, we examined whether defects in Chk2 or ATM, the main upstream activators of p53 in response to genotoxic damage, may substitute for TP53 mutations, rendering tumour cells resistant to chemotherapy. Indeed, although rare, we found non-sense mutations in the CHEK2 gene may substitute for TP53 mutations causing anthracycline resistance in primary breast cancers. $^{25,72}$ These mutations caused early stop codons with complete loss of protein expression. In contrast, tumours harbouring CHEK2 missense mutations, including I157T, shown to infer a marginal elevated risk of breast cancer, ${ }^{71}$ seemed to respond normally to therapy. Among tumours resistant to anthracyclines lacking mutations in either TP53 or CHEK2, we found low ATM expression levels (but not ATM mutations) to predict anthracycline/mitomycin resistance. ${ }^{67}$ These findings link ATM and chk2 to p53 activation in response to DNA damage in breast cancer, and may be of significant importance to our understanding of tumour biology and therapy as well.

Regarding p53's downstream targets, these genes are seemingly organized in multiple redundant pathways, ${ }^{73,74}$ and inactivating mutations are likely to be compensated for when tumour cells are exposed to cytotoxic stress. In addition, some of p53's downstream targets, such as CDKN1A (coding for p21), have a very low mutation frequency in cancers, making assessment of their impact on therapy response challenging. ${ }^{75,76}$ However, Zenz et al. $^{77}$ found expression of miR-34a, a p53-inducible micro-RNA, to predict resistance to fludarabine in chronic lymphatic leukemias independent of TP53 and 17p deletion status.

\section{TP53 ANALOGUES TP63 AND TP73}

In mouse models, loss of p63 function causes skin and limb defects with neonatal death; in contrast, loss of p73 function not only causes neurological defects but an increased cancer risk as well. ${ }^{78}$ Although TP63 germline mutations cause multiple limb and skin defects in humans, ${ }^{79}$ to the best of our knowledge germline mutations in TP73 have not been detected.

The evolutionary conserved TP53 homologues TP63 and TP73 express different splice variants, some of which execute functions resembling wild-type p53 with respect to, for example, G1 cell cycle arrest and apoptosis (for details see refs 78,80 ). The issue is complicated by the fact that different isoforms, like Tap73 and $\Delta \mathrm{Np} 73$, act like antagonists to each other; the former being proapoptotic and the latter being anti-apoptotic. ${ }^{81}$ Experimental evidence has linked p73 in particular, but also p63 to tumour suppression as well as to DNA damage response. ${ }^{81-84}$ Both p63 and p73 isoforms have been linked to resistance to cisplatinum in ovarian as well as triple-negative breast cancer cells lines. ${ }^{85,86}$ Data from human studies are few, but one study found high expression of the p73-dominant negative isoforms ( $\Delta N p 73$ and $\Delta N^{\prime} p 73$ ) to be associated with platinum resistance in ovarian cancers harbouring TP53 mutations.

\section{MDM2 AND MDM4}

Although MDM2 and MDM4 execute their oncogenic effects by overexpression, the importance of each protein and lack of redundancy are illustrated by the fact that MDM2 and MDMX (the mouse homologue of MDM4) deletion in mice cause embryonic lethality, the former at the blastula stage and the latter 7-11 days into the gestation period. ${ }^{88}$

No germline mutations inactivating MDM2 has been reported in humans (probably because these would, such as in mice, be lethal at an early embryonic stage). However, interestingly, two promoter single-nucleotide polymorphisms (SNPs) influencing 
MDM2 expression levels have been associated with cancer risk. ${ }^{89-91}$ These SNPs are located in the so-called promoter P2, activated by factors like p53 in response to genotoxic stress. ${ }^{92}$ A second promoter, P1, regulates MDM2 levels under 'non-stressed' conditions, and PTEN is a major ligand suppressing basal MDM2 expression levels. ${ }^{93}$ Although Gajjer et al. ${ }^{94}$ found MDM2 to suppress p53 protein levels under non-stressed conditions, following ATM-dependent phosphorylation of MDM2 at serine 395 , the MDM2 protein became a stabilizer of p53 mRNA in response to stress. The potential impact of these findings yet remains to be settled. Although intronic SNPs in the MDM4 gene have been related to cancer risk, ${ }^{95}$ so far no functional explanation for these findings have been presented. Taken together, these findings, implicating a role of several MDM2 promoter SNPs in cancer risk, suggest MDM2 (and probably MDM4) promoter somatic mutations should be explored as a potential cause of chemoresistance.

MDM2 binds and ubiquitinates p53, thereby targeting it for degradation. In addition, MDM2 binds to and inhibits the retinoblastoma (RB) protein, ${ }^{96}$ causing the release of E2F1, which it further activates through direct binding. ${ }^{97}$ Notably, MDM2 inhibition has been shown to induce apoptosis through the E2F1p73 pathway in p53-deficient cells. ${ }^{98}$ Somatic MDM2 amplification has been considered an alternative mechanism of p53 inactivation, and is commonly recorded in soft tissue and osteosarcomas and gliomas, less frequently in melanomas and colon cancer. ${ }^{99-102}$ Amplifications of MDM4 has been reported albeit at low incidence in breast cancers and gliomas, ${ }^{102,103}$ and in retinoblastomas (RBs), for which experimental evidence indicates a role in tumour progression. ${ }^{104}$ Interestingly, MDM4 overexpression has been associated with lack of response to the MDM2 antagonist nutlin in chronic lymphoma cells in vitro. ${ }^{105}$ In a recent phase I study exploring an MDM2 antagonist administered as monotherapy to patients with liposarcomas, for which most were amplified for MDM2, one patient achieved a partial tumour response while several had stable disease, ${ }^{106}$ advocating further studies in concert with chemotherapy.

\section{THE RB-E2F1 PATHWAY}

Germline mutations affecting the RB1 gene cause RBs in young children. Now, with improved therapy and better survival for their RBs it has become clear that these individuals have an increased risk of other cancers later in life as well. ${ }^{107}$

Somatic alterations of $R B 1$, including large deletions and promoter methylations, have been detected in different cancer forms, including breast cancer (see references in Berge et $a^{108}{ }^{108}$ ). In a recent paper, Witkiewicz et al. ${ }^{109}$ found an RB-deficiency gene expression signature to be associated with increased chance of a pathological complete response among breast cancer patients receiving primary chemotherapy with 5-fluorouracil, adriamycin and cyclophosphamide, but also patients treated with combined anthracycline- and taxane-containing regimens. In contrast, we found $R B 1$ point mutations and intragenic deletions, albeit rare, to be associated with lack of response to anthracyclines and mitomycin in primary as well as metastatic breast cancers. ${ }^{108,110}$ Interestingly, these mutations were located in the protein pocket domain and have never been reported as germline mutations in RB families (Table 2).

Experimental evidence have revealed the RB protein to have an important role in execution of cell cycle arrest and cell senescence. ${ }^{111-113}$ Although a pro-apoptotic function has been reported, ${ }^{114,115}$ many studies have found loss of RB function to enhance apoptosis due to inappropriate S-phase control, ${ }^{116-118}$ causing increased sensitivity to taxanes as well as platinum compounds in different cell lines. ${ }^{19,120}$ In contrast, p53-induced apoptosis in response to doxorubicin and combined treatment with metotrexat and 5-fluorouracil has been found to be blunted
Table 2. RB1 mutations observed in 3 series of breast cancer patients $(9,21,22)$ with defined in vivo response to neoadjuvant anthracycline or mitomycin treatment (total $n=176$ )

\begin{tabular}{llc|}
\hline Mutation $^{\mathrm{a}}$ & Amino acid change & Response $^{\mathrm{b}}$ \\
\hline del exon 13-27 & & PD \\
C1819A & L607I & PD \\
C1861T & R621C & PD \\
A2092T & R698W & PR \\
del exon 21-23 & & PD \\
\hline
\end{tabular}

Abbreviations: $\mathrm{PD}$, progressive disease; $\mathrm{PR}$, partial response; $\mathrm{SD}$, stable disease; $C R$, complete response. ${ }^{a}$ None of these mutations have previously been reported (according to the Leiden open Variation Database for RB1 (rb1-lovd.d-lohmann.de)). ${ }^{b}$ Response to therapy defined as PD, SD, $\mathrm{PR}$ or $\mathrm{CR}$.

following RB knockdown in different cell lines. ${ }^{121}$ Interestingly, Schmitt et al. ${ }^{41}$ reported the p53 and the p16/RB pathway to act in concert, inducing senescence and leading to tumour regression in response to cyclophosphamide treatment in a murine model. Notably, others ${ }^{122}$ reported senescence to occur in response to doxorubicin at low doses, whereas higher doses caused quiescence in cell cultures.

The cross talk between the RB and p53 pathway is complicated. In addition to MDM2's role as a regulator of both p53 and pRB function described above, ATM and chk2 has been shown to activate E2F1 by phosphorylations, ${ }^{123,124}$ and E2F1 has been reported to activate pro-apoptotic genes, including TP73, as well as to activate ATM, causing phosphorylation of chk2 and p53 in response to DNA damage. ${ }^{125,126}$ Further, p21, regulating pRB function through inhibition/induction of cyclin/cdk complexes, ${ }^{127}$ is a direct target for transcriptional activation by p53 (Figure 3).

\section{HER-2 AMPLIFICATION AND CHEMORESISTANCE}

HER-2 amplification is associated with a poor prognosis in primary breast cancers not receiving adjuvant therapy. ${ }^{128,129}$ Although treatment with trastuzumab dramatically improves relapse-free survival in the adjuvant setting, ${ }^{130}$ the percentage of patients with HER-2-amplified tumours that relapsed following adjuvant chemotherapy with trastuzumab resembles the relapse rate among patients with non-amplified tumours. Similar to nonamplified tumours, HER-2-amplified tumours are subject to therapy failure with respect to chemotherapy as well as endocrine treatment; ${ }^{8}$ thus, the same mechanisms causing resistance in HER-2 non-amplified tumours are likely to operate in the amplified tumours as well. In addition, failure on trastuzumab may relate to HER-2-specific mechanisms; thus, treatment with the HER-2 thyrosine kinase inhibitor lapatinib and trastuzumab in concert were found to be more effective as compared with lapatinib monotherapy in patients failing trastuzumab treatment, ${ }^{131}$ and adding pertuzumab, an antibody specifically blocking HER-2/HER-3 dimerization, improved treatment with trastuzumab and chemotherapy. ${ }^{132}$

HER-2 amplification has been associated with anthracycline sensitivity. Thus, HER-2-positive breast cancers gain an additional benefit from anthracycline-containing chemotherapy, but require higher doses compared with non-amplified tumours. ${ }^{133-136}$ Yet, it is not clear whether this effect is due to HER-2 overexpression as such, or due to co-amplification of Topo-II. The TOPO-Il gene is located close to HER-2 on chromosome $17 \mathrm{q}$, and is co-amplified in about $40 \%$ of HER-2-amplified breast cancers. ${ }^{137}$ Topo-II is a major target for anthracycline compounds, and several studies have reported TOPO-II amplification to be a better predictor of anthracycline sensitivity compared with HER-2 


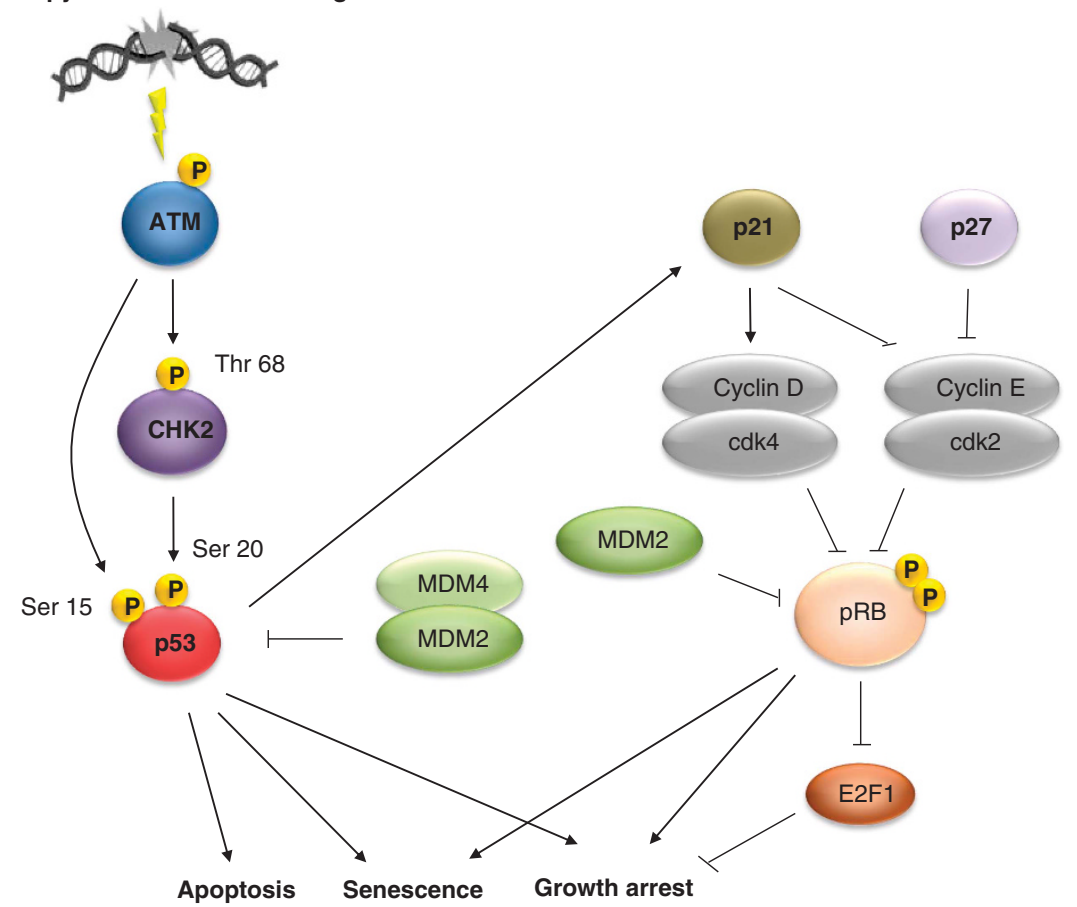

Figure 3. The p53 and RB functional pathways. Schematic representation of the activation of central factors in the p53 pathway upon DNA damage (for example, induced by chemotherapy) as well as the cross talk between p53 and the RB pathway.

amplifications. $^{138-140}$ Although experimental evidence do not suggest HER-2 overexpression to cause drug resistance, ${ }^{141}$ interestingly, one study ${ }^{142}$ found HER-2 overexpression to be associated with improved response when adding a taxane to anthracycline-containing chemotherapy in breast cancer patients. Finally, HER-2 activates the PI3K/akt/mTOR pathway, discussed in detail below. In conclusion, these data indicate we are dealing with a 'response sensitizer' and not a mechanism of resistance blocking the effect of chemotherapy.

\section{ACTIVATING MUTATIONS IN THE PTEN/PI3K/MTOR PATHWAY AS A CAUSE OF THERAPY RESISTANCE}

The PTEN/PI3K/mTOR pathway has recently been reviewed in detail by Baselga. ${ }^{143}$ Germline mutations in the PTEN gene cause the Bannayan-Riley-Ruvalcaba syndrome or the Cowden syndrome. Although they both cause hamartomas and several other characteristics, individuals carrying the Cowden syndrome are also prone to elevated cancer risk, in particular cancers of the thyroid and breast. ${ }^{144}$ While germline mutations in PIK3CA and AKT3 (the Akt isoform expressed in neural tissue) may cause megalencephaly, ${ }^{145}$ a most recent study ${ }^{146}$ reported PI3KCA, but also AKT1 germline mutations in some families revealing the Cowden or a Cowden-like syndrome.

Breast cancer patients with oestrogen receptor-positive tumours revealing HER-2 amplification have been shown to respond poorly to endocrine therapy with aromatase inhibitors as well as tamoxifen. ${ }^{147}$ Adding trastuzumab ${ }^{148}$ or lapatinib ${ }^{149}$ in concert improves response to aromatase inhibitors. The finding that mTOR inhibition may reverse resistance to endocrine agents in breast cancer MCF-7 cells ${ }^{150,151}$ is consistent with clinical findings; recently, two studies reported addition of the mTOR inhibitor everolimus to endocrine therapy with the aromatase inhibitor exemestane ${ }^{152}$ or the anti-oestrogen tamoxifen, ${ }^{153}$ to significantly improve response to therapy in cancers nonamplified for HER-2. Although these findings indicate elevated
Akt/mTOR activity as a cause of endocrine resistance in breast cancer, notably mTOR inhibition may have anti-tumour effects in other malignant conditions, including renal cancer, ${ }^{154}$ although it works less efficient in other tumour types like endometrial carcinomas. $^{155}$

The Akt/mTOR pathway may be activated through cell surface receptors like the insulin-like growth factor 1 receptor and HER-2, but in addition through pathological activation of the PI3K/Akt system. Thus, activating mutations in exons 9 or 20 in the PI3K subunit PIK3CA have been detected in 15-25\% of all breast cancers, ${ }^{156}$ but are seen more frequently among oestrogen receptor-positive tumours belonging to the luminal A class. ${ }^{157}$ In addition, approximately $5 \%$ of breast cancers may harbour activating mutations in $A K T^{158}$ The fact that strong immunostaining for Akt has been associated with a poor prognosis in breast cancer patients independent of adjuvant therapy ${ }^{159-161}$ indicates a general prognostic role for activation of the PI3K/Akt system in breast cancer. Notably, experimental evidence has linked activation of the Akt/mTOR pathway to a number of biological processes; overexpressing Akt has been shown to enhance lymphangiogenesis and confer resistance to cyclophosphamide as well as doxorubicin in murine models, ${ }^{162}$ effects that are reversed by blocking Akt's downstream effector mTOR by rapamycin. Further, mTOR inhibitors like rapamycin and everolimus have been shown to inhibit growth of triple-negative breast cancer cell lines, reverse doxorubicin resistance and enhance docetaxel effects in vitro. ${ }^{163-165}$ Finally, experimental evidence has linked elevated Akt activity to enhanced p53 degradation, ${ }^{166}$ and there is evidence for synergistic interactions between PI3K and poly(ADP-ribose) polymerase (PARP) inhibition, ${ }^{167}$ thus linking Akt activity to the p53 pathway as well as homologous end repair.

PTEN has a role in several biological processes. Thus, although much focus has been on its role as a suppressor of PI3K activity, ${ }_{1}^{143}$ notably, PTEN has also been involved in maintaining chromosomal integrity, ${ }^{168}$ and it interacts with the p53 pathway on several 
levels. Thus, whereas p53 enhances PTEN transcription, PTEN physically stabilizes the p53 protein by direct interaction, in addition to transcriptional downregulation of MDM2 through the P1 promoter and inhibition of Akt-dependent MDM2 phosphorylations..$^{93,169-173}$ DNA damage, on the other hand may lead to p53-dependent degradation of Akt. ${ }^{174}$ Although somatic mutations in PTEN occurs at high frequency in some cancers, like endometrial carcinomas, they are rare in breast cancer. ${ }^{175}$ In contrast, PTEN protein expression is absent in about $40 \%$ of all breast cancers. ${ }^{176-178}$ Although PTEN promoter methylation has been reported, ${ }^{179}$ an unknown but probably high proportion of these findings relate to cross-reactions with the pseudogene PTENP1. ${ }^{180}$ Studying prostatic cancer, Pandolfi and co-workers ${ }^{181,182}$ have shown PTENP1 to be transcribed and have provided evidence indicating it may act as a decoy, competing with the PTEN transcript for miRNA binding. If these findings are confirmed in other cancer forms as well, it may have significant implications to our understanding of PTEN regulation, but probably regulation of other genes as well.

Although the full mechanisms remains to be elucidated, mTOR activity should be clearly explored as a potential mechanism of resistance towards endocrine therapy and, probably, chemotherapy as well.

\section{DNA REPAIR PATHWAYS}

For a detailed outline of the different mechanisms of DNA repair, the readers are referred to recent reviews. ${ }^{183-185}$ Here we will discuss contemporary knowledge linking disturbances in DNA repair pathways to therapy sensitivity/resistance and compare this with findings related to cancer risk syndromes.

As for DNA repair, six mechanisms have been identified; these include nucleotide excision repair (NER), base excision repair (BER), homologous recombination repair (HRR), non-homologous end joining (NHEJ), mismatch repair (MMR) and $\mathrm{O}^{6}$-methyl-guanine-
DNA methyltrasferase (MGMT; Figure 4). Although the type of DNA lesion preferentially targeted by each mechanism is known, ${ }^{183}$ notably, there is evidence for direct interaction between components of the different repair systems as well as between DNA repair and the p53 pathway. ${ }^{186-194}$

Although loss of apoptotic/senescent function in theory should be expected to cause therapy resistance, the opposite may be the case in DNA repair. Drugs like alkylating agents generate 8-oxoguanine and single-strand breaks subject to repair by BER, whereas platinum-containing compounds generate interstrand crosslinks and double-strand breaks. ${ }^{185}$ Leaving such serious DNA lesions intact without any repair may subsequently lead to cell death.

\section{NUCLEOTIDE EXCISION REPAIR}

NERs include multiple components involved in bulky adduct and intrastrand crosslink repair in response to different damaging agents, including UV light. ${ }^{185}$

Germline mutations affecting NER is the cause of the autosomal recessive disorder xeroderma pigmentosum, associated with a profoundly elevated risk of all types of cancers of the skin. ${ }^{195,196}$

Although HRR is considered the major mechanism inactivating platinum-generated adducts, ${ }^{197}$ experimental studies have implicated a role for NER as well. ${ }^{198}$ Interestingly, experimental but also clinical evidence have linked expression levels of ERCC1, a component of the NER pathway, to lack of sensitivity to platinum compounds in different malignant conditions, including cancers of the ovary, ${ }^{199}$ stomach, $^{200}$ endometrium $^{201}$ and lung, as well as head and neck cancer-derived cell lines. ${ }^{202,203}$ The fact that ERCC1 expression levels correlated to poor survival in lung cancer patients treated with platinum-based chemotherapy ${ }^{204}$ indicates an association between ERCC1 expression levels and chemosensitivity, although a prognostic effect not related to therapy may not be excluded. Further, homozygosity for a SNP
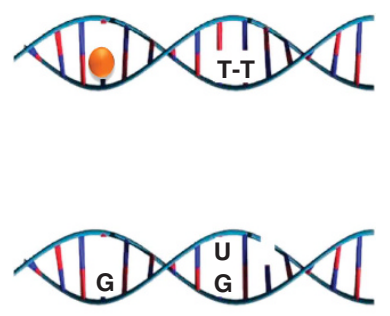

Abasic site

Uracil

Single-strand break

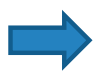

BER

Bulky adducts

Pyrimidine dimers
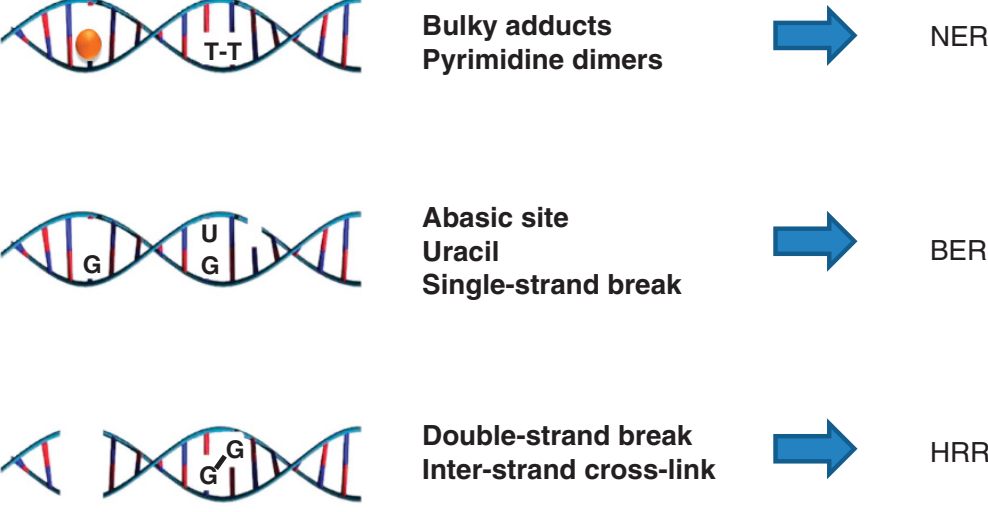

Double-strand break

Inter-strand cross-link

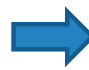

HRR / NHEJ

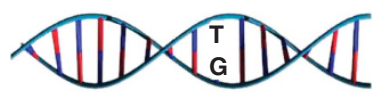

Basepair mismatch

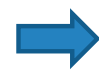

MMR

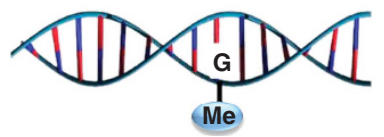

Guanine alkylation

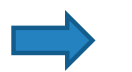

MGMT

Figure 4. Mechanisms of DNA repair. Different classes of DNA damage and the cellular mechanisms involved in repairing these. NER, nucleotide excision repair; BER, base excision repair; HRR, homologous recombination repair; NHEJ, non-homologous end joining; MMR, mismatch repair; and MGMT, $\mathrm{O}^{6}$-methyl-guanine-DNA methyltransferase. 
variant associated with lower enzyme activity of the xeroderma pigmentosum group $D$ gene has been linked to higher response rate to combined treatment with 5 -fluorouracil and oxaliplatin in colorectal cancer. ${ }^{205}$

\section{BASE EXCISION REPAIR}

Although germline mutations in BER genes have not been detected in any cancer risk syndromes, conflicting evidence has linked polymorphisms to risk of melanoma as well as cancers of the breast and bladder (see references in Santonocito et al. ${ }^{206}$ ). Experimental evidence has linked expression levels of Pol- $\beta$, a key component of the BER pathway, to resistance to oxaliplatin across a panel of different cell lines, ${ }^{207}$ but so far we lack data from clinical studies. BER however has an important role with respect to so-called 'synthetic lethality' through PARP inhibition; this topic is discussed below with respect to HRR.

\section{HOMOLOGOUS RECOMBINATION REPAIR}

Although the role of $B R C A 1 / 2$ mutations inferring enhanced risk of breast and ovarian cancer is well documented, ${ }^{208,209}$ germline mutations affecting other genes in the Fanconi complex (see below) like PALB2 (FANCN) and BRIP1 (FANC) has been associated with elevated risk for ovarian cancer. ${ }^{210,211}$ In addition, germline mutations in RAD51C and RAD51D, more recently shown to interact with the Fanconi pathway ${ }^{212}$ as well as RAD51 and the BRCA1 co-factor BARD, have all been associated with predisposition to breast and/or ovarian cancer. ${ }^{213-215}$ These findings, revealing defects in the Fanconi pathway beyond $B R C A 1 / 2$ mutations to be associated with cancer risk, advocate disturbances in other Fanconi complex components to be examined with respect to drug sensitivity/resistance as well (see below).

$B R C A 1$ and BRCA2 have a key role in HRR. BRCA2 is part of the Fanconi complex (FANCD1), whereas BRCA1 has a critical role as a downstream executor from the complex (see Valerie et al., ${ }^{216}$ and Garcia and Benitez ${ }^{217}$ for details). In contrast to BRCA2-mutated tumours that display gene expression profiles resembling spontaneous breast cancers, about $80 \%$ of all breast cancers developing in individuals carrying a $B R C A 1$ mutation reveal a gene expression profile resembling the so-called 'basal-like' breast cancers.

Although the term 'triple-negative', (meaning tumours lacking expression of the oestrogen and progesterone receptors, as well as being non-amplified for HER-2) sometimes is used synonymous to 'basal-like' breast cancers, notably only between $60-80 \%$ of all triple-negative breast cancers are actually classified as 'basal-like' based on gene expression or protein biomarker profiling. ${ }^{218,219}$ Studies evaluating pre-surgical chemotherapy for primary breast cancers reported a higher complete response rate to anthracycline- ${ }^{220-222}$ and to platinum-containing 223,224 regimens for triple-negative as compared with other breast cancers. Although about $10 \%$ of all basal-like breast cancers have been diagnosed in BRCA1 germline mutation carriers, ${ }^{225}$ currently we have limited knowledge whether other components of the Fanconi system are disturbed in triple-negative/basal-like breast cancer.

In contrast to triple-negative breast cancers, the number of patients harbouring BRCA1/2-mutated tumours enrolled in studies evaluating predictive factors is low; thus, current evidence should be interpreted with caution. Conflicting evidence indicate little difference in response to anthracycline-containing chemotherapy for $B R C A 1 / 2$ mutation carriers as compared with individuals harbouring wild-type $B R C A 1 / 2$ in primary as well as metastatic breast cancer. ${ }^{226-228}$ Regarding platinum-containing therapy for breast cancer patients with BRCA1/2 mutations, anecdotical evidence indicate a high complete response rate to such regimens in the primary setting. ${ }^{229,230}$ In contrast, $B R C A 1$ mutation carriers have been reported to respond poorly to taxane-based chemotherapy for metastatic breast cancer. ${ }^{231}$ Notably, BRCA1 downregulation has been shown to confer taxane resistance in MCF-7 cells owing to premature inactivation of the spindle checkpoint. ${ }^{232}$

Although BRCA1/2 germline mutations are rare in breast cancer, they may account for $10-15 \%$ of all cases of ovarian cancers (see Alsop et al. $^{233}$ with references). Owing to 'debulking surgery', ovarian cancer patients undergoing chemotherapy often have non-measurable disease; thus, progression within 6 months of completing first-line platinum-based chemotherapy has been defined as drug resistance. ${ }^{234}$ Several studies have revealed ovarian cancer patients with BRCA1 as well as BRCA2 germline mutations to have a better chance of responding to platinumbased therapy as compared with patients wild type for BRCA1/2 in the primary setting as well as on tumour relapse. ${ }^{233,235-238}$ Most interestingly, there is experimental (BRCA2) but also results in human tumours (BRCA1 and BRCA2) revealing secondary mutations, restoring $B R C A 1 / 2$ protein function, to be associated with acquired resistance toward platinum compounds. ${ }^{239-242}$

The fact that mutations affecting both $B R C A 1$ and $B R C A 2$ seem to confer sensitivity to platinum compounds and to PARP inhibitors (see below) clearly implicates the Fanconi complex in drug sensitivity to these compounds. Although little is known with respect to effects of defects in other components of the Fanconi complex on drug sensitivity, interestingly defects in RAD51D has been shown to enhance sensitivity to cisplatin in mouse cells. ${ }^{243}$

The concept of 'synthetic lethality' in cancer treatment was proposed by Hartwell et al. in 1997. ${ }^{244}$ Eight years later, two groups ${ }^{245,246}$ independently reported killing of BRCA1/2-mutated cells with use of PARP inhibitors. PARP has a critical role to BER and single DNA strand repair; in case of PARP inhibition, such lesions may proceed to double-strand breaks, to be handled by HRR. $^{247}$ Thus, ovarian and breast cancer cells harbouring BRCA1/2 mutations that, in most cases are accompanied by loss of the healthy allele, ${ }^{248}$ are sensitized to the toxic effect of PARP inhibitors. Several studies have confirmed anti-tumour effects in human breast and ovarian cancers in patients carrying BRCA1 or BRCA2 germline mutations. ${ }^{249-254}$ of note, although ovarian cancer patients treated for high-grade epithelial cancers not harbouring BRCA1/2 germline mutations responded to PARP inhibition with Olaparib with a response rate similar to that of BRCA1/2 mutation carriers, no response to Olaparib monotherapy was recorded among patients treated for triple-negative breast cancer harbouring wild-type BRCA1/2. ${ }^{253}$ BRCA1/2 somatic and germline mutations are observed more frequently in ovarian $(>20 \%)$ as compared with breast cancers; ${ }^{255}$ yet, the finding of a high response rate to PARP inhibitors in high-grade ovarian cancers suggests alternative mechanisms of HRR inactivation may operate in addition. Although the ovarian cancer genome atlas reported a low incidence of mutations in other genes involved in the Fanconi complex, ${ }^{256}$ there may be other mechanisms involved, including miRNA-mediated downregulation of BRCA1, ${ }^{257}$ which has been reported in triple-negative breast cancers. ${ }^{258}$ Anecdotically, a remarkable response to mitomycin was observed in a patient with pancreatic cancer harbouring biallelic PALB2 mutations. ${ }^{259}$

Although PARP inhibitors administered as monotherapy was found ineffective in triple-negative breast cancer, experimental evidence has indicated synergistic lethality between cisplatin and PARP inhibitors in triple-negative breast cancer cells not harbouring BRCA1/2 mutations. ${ }^{260}$ Adding a second PARP inhibitor, Iniparib, to treatment with gemcitabine and carboplatin improved response rates and time to progression in patients with metastatic triple-negative breast cancer in a phase II study; ${ }^{261}$ however, a phase III follow-up study failed to confirm significant 
improvement. $^{262}$ Notably, recent experimental evidence has thrown doubt on the efficacy of Iniparib as a PARP inhibitor. ${ }^{263}$ Although PARP may interact with multiple processes involved in DNA damage response ${ }^{264}$ and experimental evidence suggested PARP inhibitors may enhance cytotoxic efficacy of different cytotoxic compounds including temozolamide in different models, ${ }^{265}$ as for today the jury is still out regarding whether PARP inhibition may have any place in the clinic for tumours wild type for $B R C A 1 / 2$ except for high-grade ovarian cancers. Immunohistochemical studies have reported reduced ${ }^{266}$ as well as elevated ${ }^{267}$ PARP expression in triple-negative compared with other types of breast cancers; interestingly, the second study ${ }^{267}$ linked elevated PARP levels to improved effect of anthracyclinetaxane combined chemotherapy

\section{NON-HOMOLOGOUS END JOINING}

Germline defects in the components of the NHEJ machinery causes syndromes characterized by immunodeficiency (SCID), radiosensitivity and mircocephaly. ${ }^{268}$ However, the role for such defects with respect to cancer is unclear. Although SNP profiles in five NHEJ-involved genes have been found to be associated with breast cancer risk, ${ }^{269}$ in vitro work in breast cancer cell lines has revealed that even though there is a large number of structural rearrangements in most cancer cell genomes, this phenomenon is not associated with major defects in the NHEJ pathway. ${ }^{270} \mathrm{~A}$ potential role for alterations of NHEJ function in therapy response remains to be elucidated.

\section{MISMATCH REPAIR}

Germline mutations in genes involved in MMR are the cause of non-polypomatous cancer of the colon, or the Lynch syndrome. In addition to elevated risk of cancer of the large bowel, the syndrome includes enhanced risk for cancer of the endometrium, ovary and the brain. The genes most frequently mutated are $\mathrm{MLH} 1$ and $M S H 2$, and more rarely MSH6 and PMS2. ${ }^{271}$

Approximately $15 \%$ of all cancers of the large bowel express the so-called 'microsatellite instability' phenotype, ${ }^{272}$ strongly associated with defects in the MMR system. ${ }^{273}$ Defects in the mismatch system has been related to inferior response to 5 -fluorouracil in cancer of the large bowel, ${ }^{272}$ but more lately to an inferior response to cisplatin in germ-cell tumours (testicular seminomas and non-seminomas) as well. ${ }^{274}$ In contrast, there is experimental evidence indicating enhanced response to methotrexate-induced oxidative damage in $\mathrm{MSH} 2$-deficient endometrial and colon cancer-derived cells, ${ }^{275}$ but reduced response to thiopurines in leukemia cells. ${ }^{276}$

\section{6-METHYL-GUANINE-DNA-METHYLTRANSFERASE}

In addition to the mechanisms described above, MGMT has a role in therapy sensitivity. MGMT acts by removing alkyl groups from the $\mathrm{O}^{6}$-position on guanine; ${ }^{277}$ thus, similar to base excision repair, it may detoxify the effect of alkylating compounds on tumour cells. Although not being subjected to mutations, MGMT downregulation due to promoter methylation has been shown to predict response to temozolomide, but not to temozolomide in concert with cisplatinum in patients with high-grade gliomas or glioblastomas. $^{278,279}$ The hypothesis that low levels of MGMT predict temozolomide efficacy is further supported by a study revealing improved survival related to MGMT methylation in glioblastoma patients receiving temozolomide therapy, ${ }^{280}$ although in this case study design do not allow a distinction between prediction and prognostication (effect of biology independent of specific therapy).

\section{WAY FORWARD}

To properly assess the predictive value of potential biomarkers, there is a need for properly designed studies. As described and depicted in Figure 1, we suggest three different ways of performing such studies: (a) comparison of outcome in patients positive or negative for a biomarker receiving different treatment regimens in the adjuvant setting, (b) comparison of biomarkers in resistant versus sensitive tumours subject to direct assessment and (c) comparison of the fraction of cells harbouring a biomarker in pre- and post-treatment samples.

Massive parallel sequencing and other emerging technologies provide novel opportunities by analyzing multiple genes in concert as well as the possibility of quantifying the percentage of cells within the tumour tissue harbouring a specific mutation. This allows the possibility to determine clonal selection or elimination during therapy (Figure 2). Although each tumour contains hundreds of different mutations and genetic alterations, it has become generally accepted that a few ones only may act as the so-called 'drivers' in carcinogenesis, contrasting the large amount of 'passengers' generated by genomic instability but contributing little to the tumour phenotype..$^{281,282}$ Substantial evidence now points that chemoresistance, to a large extent, may be due to disturbances in a limited number of 'gene cascades' or 'functional pathways'. This relates, in particular, to gene pathways involved in apoptosis/senescence and DNA repair. As for most of these pathways, they contain proteins coded for by genes involved in inherited cancer syndromes. Thus, these genes may be coined 'beacons' or, perhaps, better 'drivers' by which the road towards drug resistance may be identified. Although some 'kinase pathways' like the akt/mTOR pathway seems to be involved as well, notably, this pathway acts in concert with tumour suppressors involved in DNA damage response as well as proteins coded for by genes involved in inherited cancer risk syndromes (such as PTEN and TP53). ${ }^{283,284}$ Notably, there are cross talks between components of these pathways, and it is likely that different pathways are of variable importance in different tissue compartments. Conceptually, this parallels what we observe for germline mutations and tissue-specific cancer forms. Although germline mutations affect every body compartment, for reasons unexplained, mutations in particular genes leave the individuals prone to cancer in particular organs. A striking example includes CDKN2A coding for p16; whereas germline mutations in this gene are associated with a high risk of melanoma, mutations affecting the RB1 gene, coding for the RB protein acting downstream of p16, are associated with RBs.

Exploring the mechanisms of drug resistance, clearly there is a need to analyze multiple genes in concert. However, while massive parallel sequencing will generate an enormous amount of interesting data from each tumour, identification of the 'drivers' of chemoresistance through analyses of all genes in a high number of tumours, with subsequent statistical assessments, without any clear hypothesis based on biology, seems a nonefficient way forward. Instead, we propose to take advantage of current biological knowledge. Concentrating efforts on DNA damage, apoptosis and DNA repair, and the key 'beacon genes'/ functional pathways involved in these processes, we believe, may lead towards successful programmes assessing the mechanisms of chemoresistance based on a limited number of genes.

\section{REFERENCES}

1 Schrohl AS, Meijer-van Gelder ME, Holten-Andersen MN, Christensen IJ, Look MP Mouridsen HT et al. Primary tumor levels of tissue inhibitor of metalloproteinases- 1 are predictive of resistance to chemotherapy in patients with metastatic breast cancer. Clin Cancer Res 2006; 12: 7054-7058.

2 Sørensen NM, Bystrom P, Christensen IJ, Berglund A, Nielsen HJ, Brunner N et al. TIMP-1 is significantly associated with objective response and survival in 
metastatic colorectal cancer patients receiving combination of irinotecan 5-fluorouracil, and folinic acid. Clin Cancer Res 2007; 13: 4117-4122.

3 McGrogan BT, Gilmartin B, Camey DN, McCann A. Taxanes microtubules and chemoresistant breast cancer. Biochim Biophys Acta 2008; 1785: 96-132.

4 Lønning PE. Genes causing inherited cancer as beacons identifying the mechanisms of chemoresistance. Trends Mol Med 2004; 10: 113-118.

5 Lønning P. Study of suboptimum treatment response: lessons from breast cancer. Lancet Oncol 2003; 4: 177-185.

6 Lønning PE, Knappskog S, Staalesen V, Chrisanthar R, Lillehaug JR. Breast cancer prognostication and prediction in the postgenomic era. Ann Oncol 2007; 18: 1293-1306

7 Rose C, Thorpe SM, Andersen KW, Pedersen BV, Mouridsen HT, Blichert-Toft M et al. Beneficial effect of adjuvant tamoxifen therapy in primary breast cancer patients with high oestrogen receptor values. Lancet 1985; 1: 16-19.

8 Lønning PE. Molecular basis for therapy resistance. Mol Oncol 2010; 4: 284-300.

9 Olivier M, Goldgar DE, Sodha N, Ohgaki H, Kleihues P, Hainaut P et al. Li-Fraumeni and related syndromes: correlation between tumor type, family structure, and TP53 genotype. Cancer Res 2003; 63: 6643-6650.

10 Dumont P, Leu JIJ, Della Pietra AC, George DL, Murphy M. The codon 72 polymorphic variants of p53 have markedly different apoptotic potential. Nat Genet 2003; 33: 357-365.

11 Ma YL, Yang JJ, Liu ZH, Zhang P, Yang Z, Wang Y et al. No significant association between the TP53 codon 72 polymorphism and breast cancer risk: a metaanalysis of 21 studies involving 24,063 subjects. Breast Cancer Res Treat 2011; 125: 201-205.

12 Geisler S, Lønning PE, Aas T, Johnsen H, Fluge O, Haugen DF et al. Influence of TP53 gene alterations and c-erbB-2 expression on the response to treatment with doxorubicin in locally advanced breast cancer. Cancer Res 2001; 61: 2505-2512.

13 Sjögren S, Inganäs $M$, Norberg T, Lindgren A, Nordgren $H$, Holmberg L et al. The p53 gene in breast cancer: prognostic value of complementary DNA sequencing versus immunohistochemistry. J Natl Cancer Inst 1996; 88: 173-182.

14 Roth JA, Nguyen D, Lawrence DD, Kemp BL, Carrasco CH, Ferson DZ et al. Retrovirus-mediated wild-type p53 gene transfer to tumors of patients with lung cancer. Nat Med 1996; 2: 985-991.

15 Lehmann S, Bykov VJN, Ali D, Andren O, Cherif H, Tidefelt U et al. Targeting p53 in vivo: a first-in-human study with p53-targeting compound APR-246 in refractory hematologic malignancies and prostate cancer. J Clin Oncol 2012; 30: 3633-3639.

16 Danks MK, Whipple DO, McPake CR, Lu DY, Harris LC. Differences in epitope accessibility of p53 monoclonal antibodies suggest at least three conformations or states of protein binding of p53 protein in human tumor cell lines. Cell Death Differ 1998; 5: 678-686

17 Lambert JMR, Gorzov P, Veprintsev DB, Soderqvist M, Segerback D, Bergman J et al. PRIMA-1 reactivates mutant p53 by covalent binding to the core domain. Cancer Cell 2009; 15: 376-388.

18 Zenz T, Eichhorst B, Busch R, Denzel T, Habe S, Winkler D et al. TP53 mutation and survival in chronic lymphocytic leukemia. J Clin Oncol 2010; 28: 4473-4479.

19 Dohner H, Fischer K, Bentz M, Hansen K, Benner A, Cabot G et al. P53 gene deletion predicts for poor survival and nonresponse to therapy with purine analogs in chronic B-cell leukemias. Blood 1995; 85: 1580-1589.

20 Diccianni MB, Yu J, Hsiao M, Mukherjee S, Shao L-E, Yu AL. Clinical significance of p53 mutations in relapsed T-cell acute lymphoblastic leukemia. Blood 1994; 84 3105-3112.

21 Wattel E, Preudhomme C, Hecquet B, Vanrumbeke M, Quesnel B, Dervite I et al. p53 mutations are associated with resistance to chemotherapy and short survival in hematologic malignancies. Blood 1994; 84: 3148-3157.

22 Preudhomme C, Dervite I, Wattel E, Vanrumbeke M, Flactif M, Lai JL et al. Clinical significance of p53 mutations in newly diagnosed Burkitt's lymphoma and acute lymphoblastic leukemia: a report of 48 cases. J Clin Oncol 1995; 13: 812-820.

23 Ichikawa A, Kinoshita T, Watanabe T, Kato H, Nagai H, Tsushita K et al. Mutations of the 553 gene as a prognostic factor in aggressive B-cell lymphoma. $N$ Engl Med 1997; 337: 529-534.

24 Geisler S, Borresen-Dale AL, Johnsen H, Aas T, Geisler J, Akslen LA et al. TP53 gene mutations predict the response to neoadjuvant treatment with 5-fluorouracil and mitomycin in locally advanced breast cancer. Clin Cancer Res 2003; 9: $5582-5588$.

25 Chrisanthar R, Knappskog S, Lokkevik E, Anker G, Ostenstad B, Lundgren S et al. CHEK2 mutations affecting kinase activity together with mutations in TP53 indicate a functional pathway associated with resistance to epirubicin in primary breast cancer. PLos One 2008; 3: e3062.

26 Kandioler-Eckersberger D, Ludwig C, Rudas M, Kappel S, Janschek E, Wenzel C et al. TP53 mutation and p53 overexpression for prediction of response to neoadjuvant treatment in breast cancer patients. Clin Cancer Res 2000; 6: 50-56.
27 Chrisanthar R, Knappskog S, Lokkevik E, Anker G, Ostenstad B, Lundgren S et al. Predictive and prognostic impact of TP53 mutations and MDM2 promoter genotype in primary breast cancer patients treated with epirubicin or paclitaxel. PLos One 2011; 6: e19249.

28 Fernandez-Cuesta L, Oakman C, Falagan-Lotsch P, Smoth KS, Quinaux E, Buyse M et al. Prognostic and predictive value of TP53 mutations in node-positive breast cancer patients treated with anthracycline- or anthracycline/taxane-based adjuvant therapy: results from the BIG 02-98 phase III trial. Breast Cancer Res 2012; 14: 3.

29 Deissler H, Kafka A, Schuster E, Sauer G, Kreienberg R, Zeillinger R. Spectrum of p53 mutations in biopsies from breast cancer patients selected for preoperative chemotherapy analysed by the functional yeast assay to predict therapeutic response. Oncol Rep 2004; 11: 1281-1286.

30 Oshima K, Naoi Y, Kishi K, Nakamura Y, Iwamoto T, Shimazu K et al. Gene expression signature of TP53 but not its mutation status predicts response to sequential paclitaxel and 5-FU/epirubicin/cyclophosphamide in human breast cancer. Cancer Lett 2011; 307: 149-157.

31 Lehmann-Che J, Andre F, Desmedt C, Mazouni C, Giacchetti S, Turpin E et al. Cyclophosphamide dose intensification may circumvent anthracycline resistance of p53 mutant breast cancers. Oncologist 2010; 15: 246-252.

32 Song SS, Xing GC, Yuan L, Wang J, Wang S, Yin YX et al. N-methylpurine DNA glycosylase inhibits p53-mediated cell cycle arrest and coordinates with p53 to determine sensitivity to alkylating agents. Cell Res 2012; 22: 1285-1303.

33 Bonnefoi H, Piccart M, Bogaerts J, Mauriac L, Fumoleau P, Brain E et al. TP53 status for prediction of sensitivity to taxane versus non-taxane neoadjuvant chemotherapy in breast cancer (EORTC 10994/BIG 1-00): a randomised phase 3 trial. Lancet Oncol 2011; 12: 527-539.

34 Righetti SC, DellaTorre G, Pilotti S, Menard S, Ottone F, Colnaghi Ml et al. A comparative study of $\mathrm{p} 53$ gene mutations, protein accumulation, and response to cisplatin-based chemotherapy in advanced ovarian carcinoma. Cancer Res 1996; 56: 689-693.

35 Lavarino C, Pilotti S, Oggionni M, Gatti L, Perego P, Bresciani G et al. p53 gene status and response to platinum/paclitaxel-based chemotherapy in advanced ovarian carcinoma. J Clin Oncol 2000; 18: 3936-3945.

36 Kandioler D, Stamatis G, Eberhardt W, Kappel S, Zochbauer-Muller S, Kuhrer I et al. Growing clinical evidence for the interaction of the p53 genotype and response to induction chemotherapy in advanced non-small cell lung cancer. $J$ Thorac Cardiovasc Surg 2008; 135: 1036-1041.

37 Kandioler-Eckersberger D, Kappel S, Mittlbock M, Dekan G, Ludwig C, Janschek E et al. The TP53 genotype but not immunohistochemical result is predictive of response to cisplatin-based neoadjuvant therapy in stage III non-small cell lung cancer. J Thorac Cardiovasc Surg 1999; 117: 744-750.

38 Toledo F, Wahl GM. Regulating the p53 pathway: in vitro hypotheses, in vivo veritas. Nat Rev Cancer 2006; 6: 909-923.

39 Morselli E, Tasdemir E, Maiuri MC, Galluzzi L, Kepp O, Criollo A et al. Mutant p53 protein localized in the cytoplasm inhibits autophagy. Cell Cycle 2008; 7: 3056-3061.

40 Vaseva AV, Marchenko ND, Ji K, Tsirka SE, Holzmann S, Moll UM. p53 opens the mitochondrial permeability transition pore to trigger necrosis. Cell 2012; 149: 1536-1548.

41 Schmitt CA, Fridman JS, Yang M, Lee S, Baranov E, Hoffman RM et al. A senescence program controlled by $\mathrm{p} 53$ and p16INK4a contributes to the outcome of cancer therapy. Cell 2002; 109: 335-346.

42 Jackson JG, Pant V, Li Q, Chang LL, Quintas-Cardama A, Garza D et al. p53mediated senescence impairs the apoptotic response to chemotherapy and clinical outcome in breast cancer. Cancer Cell 2012; 21: 793-806.

43 Smeenk L, van Heeringen SJ, Koeppel M, Gilbert B, Janssen-Megens E, Stunnenberg HG et al. Role of p53 serine 46 in p53 target gene regulation. Plos One 2011; 6: 3 .

44 Feng LJ, Hollstein M, Xu Y. Ser46 phosphorylation regulates p53-dependent apoptosis and replicative senescence. Cell Cycle 2006; 5: 2812-2819.

45 Mayo LD, Seo YR, Jackson MW, Smith ML, Guzman JR, Korgaonkar CK et al. Phosphorylation of human p53 at serine 46 determines promoter selection and whether apoptosis is attenuated or amplified. J Biol Chem 2005; 280: 25953-25959.

46 Morachis JM, Murawsky CM, Emerson BM. Regulation of the p53 transcriptional response by structurally diverse core promoters. Genes Dev 2010; 24: 135-147.

47 Qian H, Wang T, Naumovski L, Lopez CD, Brachmann RK. Groups of p53 target genes involved in specific p53 downstream effects cluster into different classes of DNA binding sites. Oncogene 2002; 21: 7901-7911.

48 Zhang XP, Liu F, Wang W. Two-phase dynamics of p53 in the DNA damage response. Proc Natl Acad Sci USA 2011; 108: 8990-8995.

49 Jemaa M, Galluzzi L, Kepp O, Boileve A, Lissa D, Senovilla L et al. Preferential killing of p53-deficient cancer cells by reversine. Cell Cycle 2012; 11: 2149-2158. 
50 Freed-Pastor WA, Prives C. Mutant p53: one name, many proteins. Genes Dev 2012; 26: 1268-1286.

51 Song $\mathrm{H}, \mathrm{Xu}$ Y. Gain of function of p53 cancer mutants in disrupting critical DNA damage response pathways. Cell Cycle 2007; 6: 1570-1573.

52 Chipuk JE, Kuwana T, Bouchier-Hayes L, Droin NM, Newmeyer D, Schuler M et al. Direct activation of Bax by p53 mediates mitochondrial membrane permeabilization and apoptosis. Science 2004; 303: 1010-1014.

53 Chipuk JE, Green DR. p53's believe it or not: Lessons on transcription-independent death. J Clin Immunol 2003; 23: 355-361.

54 Bourdon JC, Fernandes K, Murray-Zmijewski F, Liu G, Diot A, Xirodimas DP et al. p53 isoforms can regulate p53 transcriptional activity. Genes Dev 2005; 19: 2122-2137.

55 Baumbusch LO, Myhre S, Langerod A, Bergamaschi A, Geisler SB, Lonning PE et al. Expression of full-length p53 and its isoform Deltap53 in breast carcinomas in relation to mutation status and clinical parameters. Mol Cancer 2006; 5: 47.

56 Bourdon JC, Khoury MP, Diot A, Baker L, Fernandes K, Aoubala M et al. p53 mutant breast cancer patients expressing p53 gamma have as good a prognosis as wild-type p53 breast cancer patients. Breast Cancer Res 2011; 13: 1.

57 Li TY, Kon N, Jiang L, Tan MJ, Ludwig T, Zhao YM et al. Tumor suppression in the absence of p53-mediated cell-cycle arrest, apoptosis, and senescence. Cell 2012 149: 1269-1283.

58 Brady CA, Jiang D, Mello SS, Johnson TM, Jarvis LA, Kozak MM et al. Distinct p53 transcriptional programs dictate acute DNA-damage responses and tumor suppression. Cell 2011; 145: 571-583.

59 Shiloh Y. ATM and ATR: networking cellular responses to DNA damage. Curr Opin Genet Develop 2001; 11: 71-77.

60 Gurley KE, Kemp CJ. Ataxia-telangiectasia mutated is not required for p53 induction and apoptosis in irradiated epithelial tissues. Mol Cancer Res 2007; 5: 1312-1318.

61 Jallepalli PV, Lengauer C, Vogelstein B, Bunz F. The Chk2 tumor suppressor is not required for p53 responses in human cancer cells. J Biol Chem 2003; 278: 20475-20479.

62 Hirao A, Cheung A, Duncan G, Girard PM, Elia AJ, Wakeham A et al. Chk2 is a tumor suppressor that regulates apoptosis in both an ataxia telangiectasia mutated (ATM)-dependent and an ATM-independent manner. Mol Cell Biol 2002 22: 6521-6532.

63 Ding H, Mao C, Li SM, Liu Q, Lin L, Chen Q. Lack of association between ATM C.1066-6T > G mutation and breast cancer risk: a meta-analysis of 8831 cases and 4957 controls. Breast Cancer Res Treat 2011; 125(2): 473-477.

64 Tavtigian SV, Oefner PJ, Babikyan D, Hartmann A, Healey S, Le Calvez-Kelm F et al. Rare, evolutionarily unlikely missense substitutions in ATM confer increased risk of breast cancer. Am J Hum Genet 2009; 85: 427-446.

65 Morrell D, Cromartie E, Swift M. Mortality and cancer incidence in 263 patients with ataxia-telangiectasia. J Natl Cancer Inst 1986; 77: 89-92.

66 Micol R, Ben Slama L, Suarez F, Le Mignot L, Beaute J, Mahlaoui N et al. Morbidity and mortality from ataxia-telangiectasia are associated with ATM genotype. J Allergy Clin Immunol 2011; 128: 382-U400.

67 Knappskog S, Chrisanthar R, Lokkevik E, Anker G, Ostenstad B, Lundgren S et al. Low expression levels of ATM may substitute for CHEK2/TP53 mutations predicting resistance towards anthracycline and mitomycin chemotherapy in breast cancer. Breast Cancer Res 2012; 14: R47.

68 Bell DW, Varley JM, Szydlo TE, Kang DH, Wahrer DCR, Shannon KE et al. Heterozygous germ line hCHK2 mutations in Li-Fraumeni syndrome. Science 1999; 286: 2528-2531.

69 Evans DG, Wu CL, Birch JM. BRCA2: a cause of Li-Fraumeni-like syndrome. J Med Genet 2008; 45: 62-63.

70 Consortium TCBCC-C. CHEK2*1100delC ans susceptibility to breast cancer: a collaborative analysis involving 10860 breast cancer cases and 9065 controls from 10 studies. Am J Hum Genet 2004; 74: 1175-1182.

71 Cybulski C, Gorski B, Huzarski T, Masojc B, Mierzejewski M, Debniak T et al. CHEK2 is a multiorgan cancer susceptibility gene. Am J Hum Genet 2004; 75: 1131-1135.

72 Staalesen V, Falck J, Geisler S, Bartkova J, Borresen-Dale AL, Lukas J et al. Alternative splicing and mutation status of CHEK2 in stage III breast cancer. Oncogene 2004; 23: 8535-8544.

73 Yoon H, Liyanarachchi S, Wright FA, Davuluri R, Lockman JC, de la Chapelle A et al. Gene expression profiling of isogenic cells with different TP53 gene dosage reveals numerous genes that are affected by TP53 dosage and identifies CSPG2 as a direct target of p53. Proc Natl Acad Sci USA 2002; 99: 15632-15637.

74 Kannan K, Amariglio N, Rechavi G, Jakob-Hirsch J, Kela I, Kaminski N et al. DNA microarrays identification of primary and secondary target genes regulated by p53. Oncogene 2001; 20: 2225-2234.

75 Staalesen V, Leirvaag B, Lillehaug JR, Lonning PE. Genetic and epigenetic changes in p21 and p21B do not correlate with resistance to doxorubicin or mitomycin and 5-fluorouracil in locally advanced breast cancer. Clin Cancer Res 2004; 10: 3438-3443.
76 Knappskog S, Chrisanthar R, Staalesen V, Borresen-Dale AL, Gram IT, Lillehaug JR et al. Mutations and polymorphisms of the p21B transcript in breast cancer. Int $J$ Cancer 2007; 121: 908-910.

77 Zenz T, Mohr J, Eldering E, Kater AP, Buhler A, Kienle D et al. miR-34a as part of the resistance network in chronic lymphocytic leukemia. Blood 2009; 113: 3801-3808.

78 Allocati N, Di llio C, De Laurenzi V. p63/p73 in the control of cell cycle and cell death. Exper Cell Res 2012; 318: 1285-1290.

79 Brunner HG, Hamel BCJ, van Bokhoven H. P63 gene mutations and human developmental syndromes. Am J Med Genet 2002; 112: 284-290.

80 Stiewe T. The p53 family in differentiation and tumorigenesis. Nat Rev Cancer 2007; 7: 165-168.

81 Tomasini R, Tsuchihara K, Wilhelm M, Fujitani M, Rufini A, Cheung CC et al. TAp73 knockout shows genomic instability with infertility and tumor suppressor functions. Genes Dev 2008; 22: 2677-2691.

82 Irwin MS, Kondo K, Marin MC, Cheng LS, Hahn WC, Kaelin WG. Chemosensitivity linked to p73 function. Cancer Cell. 2003; 3: 403-410.

83 Bergamaschi D, Gasco M, Hiller L, Sullivan A, Syed N, Trigiante G et al. p53 polymorphism influences response in cancer chemotherapy via modulation of p73-dependent apoptosis. Cancer Cell 2003; 3: 387-402.

84 Flores ER, Tsai KY, Crowley D, Sengupta S, Yang A, McKeon F et al. p63 and p73 are required for $\mathrm{p} 53$-dependent apoptosis in response to DNA damage. Nature 2002; 416: 560-564.

85 Leong CO, Vidnovic N, DeYoung MP, Sgroi D, Ellisen LW. The p63/p73 network mediates chemosensitivity to cisplatin in a biologically defined subset of primary breast cancers. J Clin Invest 2007; 117: 1370-1380.

86 Al-Bahlani S, Fraser M, Wong AYC, Sayan BS, Bergeron R, Melino G et al. P73 regulates cisplatin-induced apoptosis in ovarian cancer cells via a calcium calpain-dependent mechanism. Oncogene 2011; 30: 4219-4230.

87 Concin N, Hofstetter G, Berger A, Gehmacher A, Reimer D, Watrowski R et al. Clinical relevance of dominant-negative p73 isoforms for responsiveness to chemotherapy and survival in ovarian cancer: Evidence for a crucial p53-p73 cross-talk in vivo. Clin Cancer Res 2005; 11: 8372-8383.

88 Marine JC, Jochemsen AG. Mdmx and Mdm2-Brothers in arms? Cell Cycle 2004; 3: $900-904$

89 Bond $\mathrm{GL}, \mathrm{Hu}$ W, Bond EE, Robins H, Lutzker SG, Arva NC et al. A single nucleotide polymorphism in the MDM2 promoter attenuates the p53 tumor suppressor pathway and accelerates tumor formation in humans. Cell 2004; 119 591-602.

90 Knappskog S, Bjornslett M, Myklebust LM, Huijts PE, Vreeswijk MP, Edvardsen $\mathrm{H}$ et al. The MDM2 promoter SNP285C/309G haplotype diminishes Sp1 transcription factor binding and reduces risk for breast and ovarian cancer in Caucasians. Cancer Cell 2011; 19: 273-282.

91 Knappskog S, Trovik J, Marcickiewicz J, Tingulstad S, Staff AC, TECsg MoMa et al. SNP285C modulates oestrogen receptor/Sp1 binding to the MDM2 promoter and reduces the risk of endometrial but not prostatic cancer. Eur J Cancer 2012 48: 1988-1996.

92 Zauberman A, Flusberg D, Haupt Y, Barak Y, Oren M. A. Functional p53 responsive intronic promoter is contained within the human $\mathrm{mdm} 2$ gene. Nucleic Acids Res 1995; 23: 2584-2592.

93 Chang CJ, Freeman DJ, Wu H. PTEN regulates Mdm2 expression through the $\mathrm{P}$ promoter. J Biol Chem 2004; 279: 29841-29848.

94 Gajjar M, Candeias MM, Malbert-Colas L, Mazars A, Fujita J, Olivares-Illana V et al. The p53 mRNA-Mdm2 interaction controls Mdm2 nuclear trafficking and is required for p53 activation following DNA damage. Cancer Cell 2012; 21: 25-35.

95 Atwal GS, Kirchhoff T, Bond EE, Monagna M, Menin C, Bertorelle R et al. Altered tumor formation and evolutionary selection of genetic variants in the human MDM4 oncogene. Proc Natl Acad SciUSA 2009; 106: 10236-10241.

96 Xiao Z-X, Chen J, Levine AJ, Modjtahedl N, Xing J, Sellers WR et al. Interaction between the retinoblastoma protein and the oncoprotein MDM2. Nature 1995 375: 694-698.

97 Martin K, Trouche D, Hagemeier C, Sørensen TS, La Thangue NE, Kouzarides T. Stimulation of E2F1/DP1 transcriptional activity by MDM2 oncoprotein. Nature 1995; 375: 691-694.

98 Ray RM, Bhattacharya S, Johnson LR. Mdm2 inhibition induces apoptosis in p53 deficient human colon cancer cells by activating p73-and E2F1-mediated expression of PUMA and Siva-1. Apoptosis 2011; 16: 35-44.

99 Sirvent N, Coindre JM, Maire G, Hostein I, Keslair F, Guillou L et al. Detection of MDM2-CDK4 amplification by fluorescence in situ hybridization in 200 paraffinembedded tumor samples: Utility in diagnosing adipocytic lesions and comparison with immunohistochemistry and real-time PCR. Am J Surg Pathol 2007 31: 1476-1489.

100 Muthusamy V, Hobbs C, Nogueira C, Cordon-Cardo C, McKee PH, Chin L et al. Amplification of CDK4 and MDM2 in malignant melanoma. Genes Chromosomes Cancer 2006; 45: 447-454. 
101 Forslund A, Zeng ZS, Qin LX, Rosenberg S, Ndubuisi M, Pincas H et al. MDM2 gene amplification is correlated to tumor progression but not to the presence of SNP309 or TP53 mutational status in primary colorectal cancers. Mol Cancer Rese 2008; 6: 205-211.

102 Riemenschneider MJ, Buschges R, Wolter M, Reifenberger J, Bostrom J, Kraus JA et al. Amplification and overexpression of the MDM4 (MDMX) gene from 1q32 in a subset of malignant gliomas without TP53 mutation or MDM2 amplification. Cancer Res 1999; 59: 6091-6096.

103 Danovi D, Meulmeester E, Pasini D, Migliorini D, Capra M, Frenk R et al. Amplification of $\mathrm{Mdmx}$ (or Mdm4) directly contributes to tumor formation by inhibiting p53 tumor suppressor activity. Mol Cell Biol 2004; 24: 5835-5843.

104 Laurie NA, Donovan SL, Shih CS, Zhang JK, Mills N, Fuller C et al. Inactivation of the p53 pathway in retinoblastoma. Nature 2006; 444: 61-66.

105 Dal Bo M, Secchiero P, Degan M, Marconi D, Bomben R, Pozzato G et al. MDM4 (MDMX) is overexpressed in chronic lymphocytic leukaemia (CLL) and marks a subset of p53wild-type CLL with a poor cytotoxic response to Nutlin-3. $\mathrm{Br} J$ Haematol 2010; 150: 237-239.

106 Ray-Coquard I, Blay JY, Italiano A, Le Cesne A, Penel N, Zhi J et al. Effect of the MDM2 antagonist RG7112 on the P53 pathway in patients with MDM2-amplified, well-differentiated or dedifferentiated liposarcoma: an exploratory proof-ofmechanism study. Lancet Oncol 2012; 13: 1133-1140.

107 Dommering $\mathrm{CJ}$, Marees $\mathrm{T}$, van der Hout $\mathrm{AH}$, Imhof SM, Meijers-Heijboer $\mathrm{H}$ Ringens $\mathrm{PJ}$ et al. RB1 mutations and second primary malignancies after hereditary retinoblastoma. Familial Cancer 2012; 11: 225-233.

108 Berge EO, Knappskog S, Geisler S, Staalesen V, Pacal M, Borresen-Dale AL et al. Identification and characterization of retinoblastoma gene mutations disturbing apoptosis in human breast cancers. Mol Cancer 2010; 9: 173.

109 Witkiewicz AK, Ertel A, McFalls J, Valsecchi ME, Schwartz GG, Knudsen ES. RBpathway disruption is associated with improved response to neoadjuvant therapy in breast cancer. Clin Cancer Res 2012; 18: 5110-5122.

110 Berge EO, Knappskog S, Lillehaug JR, Lonning PE. Alterations of the retinoblastoma gene in metastatic breast cancer. Clin Exp Metastasis 2011; 28: 319-326.

111 Burkhart DL, Sage J. Cellular mechanisms of tumour suppression by the retinoblastoma gene. Nat Rev Cancer 2008; 8: 671-682.

112 Akakura S, Nochajski P, Gao LQ, Sotomayor P, Matsui S, Gelman IH. Rb-dependent cellular senescence, multinucleation and susceptibility to oncogenic transformation through PKC scaffolding by SSeCKS/AKAP12. Cell Cycle 2010; 9: 4656-4665.

113 Knudsen ES, Knudsen KE. Tailoring to RB: tumour suppressor status and therapeutic response. Nat Rev Cancer 2008; 8: 714-724.

114 lanari A, Natale T, Calo E, Ferretti E, Alesse E, Screpanti I et al. Proapoptotic function of the retinoblastoma tumor suppressor protein. Cancer Cell 2009; 15: 184-194.

115 Bowen C, Spiegel S, Gelmann EP. Radiation-induced apoptosis mediated by retinoblastoma protein. Cancer Res 1998; 58: 3275-3281.

116 Almasan A, Yin YX, Kelly RE, Lee E, Bradley A, Li WW et al. Deficiency of retinoblastoma protein leads to inappropriate s-phase entry, activation of e2fresponsive genes, and apoptosis. Proc Natl Acad Sci USA 1995; 92: 5436-5440.

117 Knudsen KE, Booth D, Naderi S, Sever-Chroneos Z, Fribourg AF, Hunton IC et al. RB-dependent S-phase response to DNA damage. Mol Cell Biol 2000; 20: 7751-7763.

118 Zagorski WA, Knudsen ES, Reed MF. Retinoblastoma deficiency increases chemosensitivity in lung cancer. Cancer Res 2007; 67: 8264-8273.

119 Bosco EE, Wang Y, Xu H, Zilfou JT, Knudsen KE, Aronow BJ et al. The retinoblastoma tumor suppressor modifies the therapeutic response of breast cancer. J Clin Invest 2007; 117: 218-228.

120 Sharma A, Comstock CES, Knudsen ES, Cao KH, Hess-Wilson JK, Morey LM et al. Retinoblastoma tumor suppressor status is a critical determinant of therapeutic response in prostate cancer cells. Cancer Res 2007; 67: 6192-6203.

121 Derenzini M, Brighenti E, Donati G, Vici M, Ceccarelli C, Santini D et al The p53-mediated sensitivity of cancer cells to chemotherapeutic agents is conditioned by the status of the retinoblastoma protein. J Pathol 2009; 219: 373-382.

122 Leontieva OV, Gudkov AV, Blagosklonny MV. Weak p53 permits senescence during cell cycle arrest. Cell Cycle 2010; 9: 4323-4327.

123 Lin WC, Lin FT, Nevins JR. Selective induction of E2F1 in response to DNA damage, mediated by ATM-dependent phosphorylation. Gene Dev 2001; 15: 1833-1844.

124 Stevens C, Smith L, La Thangue NB. Chk2 activates E2F-1 in response to DNA damage. Nat Cell Biol 2003; 5: 401-409.

125 Pediconi N, lanari A, Costanzo A, Belloni L, Gallo R, Cimino L et al. Differential regulation of E2F1 apoptotic target genes in response to DNA damage. Nat Cell Biol 2003; 5: 552-558.
126 Powers JT, Hong SK, Mayhew CN, Rogers PM, Knudsen ES, Johnson DG. E2F1 uses the ATM signaling pathway to induce p53 and Chk2 phosphorylation and apoptosis. Mol Cancer Res 2004; 2: 203-214.

127 Eldeiry WS, Tokino T, Velculescu VE, Levy DB, Parsons R, Trent JM et al. WAF1, a potential mediator of p53 tumor suppression. Cell 1993; 75: 817-825.

128 Slamon DJ, Clark GM, Wong SG, Levin WJ, Ullrich A, McGuire WL. Human breast cancer: correlation of relapse and survival with amplification of the HER-2/neu oncogene. Science 1987; 235: 177-182.

129 Slamon DJ, Godolphin W, Jones LA, Holt JA, Wong SG, Keith DE et al. Studies of the HER-2/neu proto-oncogene in human breast and ovarian cancer. Science 1989; 244: 707-712.

130 Romond EH, Perez EA, Bryant J, Suman VJ, Geyer Jr CE, Davidson NE et al. Trastuzumab plus adjuvant chemotherapy for operable HER2-positive breast cancer. N Engl J Med 2005; 353: 1673-1684.

131 Blackwell KL, Burstein HJ, Storniolo AM, Rugo HS, Sledge G, Aktan G et al. Overall survival benefit with lapatinib in combination with trastuzumab for patients with human epidermal growth factor receptor 2-positive metastatic breast cancer: final results from the EGF104900 Study. J Clin Oncol 2012; 30: 2585-2592.

132 Baselga J, Cortes J, Kim SB, Im SA, Hegg R, Im YH et al. Pertuzumab plus trastuzumab plus docetaxel for metastatic breast cancer. N Engl J Med 2012; 366: 109-119.

133 Muss HB, Thor AD, Berry DA, Kute T, Liu ET, Koerner F et al. c-erB-2 expression and response to adjuvant therapy in women with node-positive early Breast cancer. N Engl J Med 1994; 330: 1260-1266.

134 Paik SM, Bryant J, Park CH, Fisher B, TanChiu E, Hyams D et al. erbB-2 and response to doxorubicin in patients with axillary lymph node-positive, hormone receptor-negative breast cancer. J Nat/ Cancer Inst 1998; 90: 1361-1370.

135 Pritchard KI, Shepherd LE, O'Malley FP, Andrulis IL, Tu D, Bramwell VH et al. HER2 and responsiveness of breast cancer to adjuvant chemotherapy. $N$ Engl J Med 2006; 354: 2103-2111.

136 Petit T, Borel C, Ghnassia J-P, Rodier J-F, Escande A, Mors R et al. Chemotherapy response of breast cancer depends on HER-status and antracycline dose intensity in the neoadjuvant setting. Clin Cancer Res 2001; 7: 1577-1581.

137 Press MF, Bernstein L, Sauter G, Zhou JY, Eiermann W, Pienkowski T et al. Topoisomerase II-alpha gene amplification as a predictor of responsiveness to anthracycline-containing chemotherapy in the Cancer International Research Group 006 clinical trial of trastuzumab (herceptin) in the adjuvant setting. Breast Cancer Res Treat 2005; 94: S54-S54.

138 Knoop AS, Knudsen H, Balslev E, Rasmussen BB, Overgaard J, Nielsen KV et al. Retrospective analysis of topoisomerase Ila amplifications and deletions as predictive markers in primary breast cancer patients randomly assigned to cyclophosphamide, methotrexate, and fluorouracil or cyclophosphamide, epirubicin, and fluorouracil: Danish Breast Cancer Cooperative Group. J Clin Oncol 2005; 23: 7483-7490.

139 Tanner M, Isola J, Wiklund T, Erikstein B, Kellokumpu-Lehtinen P, Malmstrom P et al. Topoisomerase II alpha gene amplification predicts favorable treatment response to tailored and dose-escalated anthracycline-based adjuvant chemotherapy in HER-2/neu-amplified breast cancer: Scandinavian Breast Group Trial 9401. J Clin Oncol 2006; 24: 2428-2436.

140 O'Malley FP, Chia S, Tu D, Shepherd LE, Levine MN, Bramwell VH et al. Topoisomerase II alpha and responsiveness of breast cancer to adjuvant chemotherapy. J Natl Cancer Inst 2009; 101: 644-650.

141 Pegram MD, Finn RS, Arzoo K, Beryt M, Pietras RJ, Slamon DJ. The effect of HER$2 /$ neu overexpression on chemotherapeutic drug sensitivity in human breast and ovarian cancer cells. Oncogene 1997; 15: 537-547.

142 Hugh J, Hanson J, Cheang MC, Nielsen TO, Perou CM, Dumontet C et al. Breast cancer subtypes and response to docetaxel in node-positive breast cancer: use of an immunohistochemical definition in the BCIRG 001 trial. J Clin Oncol 2009; 27: 1168-1176.

143 Baselga J. Targeting the phosphoinositide-3 (PI3) kinase pathway in breast cancer. Oncologist 2011; 16: 12-19.

144 Lachlan KL, Lucassen AM, Bunyan D, Temple IK. Cowden syndrome and Bannayan-Riley-Ruvalcaba syndrome represent one condition with variable expression and age-related penetrance: results of a clinical study of PTEN mutation carriers. J Med Genet 2007; 44: 9.

145 Riviere JB, Mirzaa GM, O'Roak BJ, Beddaoui M, Alcantara D, Conway RL et al. De novo germline and postzygotic mutations in AKT3, PIK3R2 and PIK3CA cause a spectrum of related megalencephaly syndromes. Nat Genet 2012; 44: 934.

146 Orloff MS, He X, Peterson C, Chen FS, Chen JL, Mester JL et al. Germline PIK3CA and AKT1 Mutations in Cowden and Cowden-like Syndromes. Am J Hum Gen 2013; 92: 76-80.

147 Dowsett M, Allred C, Knox J, Quinn E, Salter J, Wale C et al. Relationship between quantitative estrogen and progesterone receptor expression and human epidermal growth factor receptor 2 (HER-2) status with recurrence in the arimidex, tamoxifen, alone or in combination trial. J Clin Oncol 2008; 26: 1059-1065. 
148 Kaufman B, Mackey JR, Clemens MR, Bapsy PP, Vaid A, Wardley A et al. Trastuzumab plus anastrozole versus anastrozole alone for the treatment of postmenopausal women with human epidermal growth factor receptor 2-positive, hormone receptor-positive metastatic breast cancer: results from the randomized phase III TAnDEM study. J Clin Oncol 2009; 27: 5529-5537.

149 Johnston S, Pippen J, Pivot X, Lichinitser M, Sadeghi S, Dieras V et al. Lapatinib combined with letrozole versus letrozole and placebo as first-line therapy for postmenopausal hormone receptor-positive metastatic breast cancer. J Clin Oncol 2009; 27: 5538-5546.

150 DeGraffenried LA, Friedrichs WE, Russell DH, Donzis EJ, Middleton AK, Silva JM et al. Inhibition of mTOR activity restores tamoxifen response in breast cancer cells with aberrant Akt activity. Clin Cancer Res 2004; 10: 8059-8067.

151 Beeram M, Tan QTN, Tekmal RR, Russell D, Middleton A, Degraffenried LA. Aktinduced endocrine therapy resistance is reversed by inhibition of mTOR signaling. Ann Oncol 2007; 18: 1323-1328.

152 Baselga J, Campone M, Piccart M, Burris HA, Rugo HS, Sahmoud T et al. Everolimus in postmenopausal hormone-receptor-positive advanced breast cancer. N Engl J Med 2012; 366: 520-529.

153 Bachelot T, Bourgier C, Cropet C, Ray-Coquard I, Ferrero JM, Freyer G et al. Randomized phase ii trial of everolimus in combination with tamoxifen in patients with hormone receptor-positive, human epidermal growth factor receptor 2-negative metastatic breast cancer with prior exposure to aromatase inhibitors: a GINECO study. J Clin Oncol 2012; 30: 2718-2724.

154 Bukowski RM. Temsirolimus: a safety and efficacy review. Expert Opin Drug Saf 2012; 11: 861-879.

155 Diaz-Padilla I, Duran I, Clarke BA, Oza AM. Biologic rationale and clinical activity of mTOR inhibitors in gynecological cancer. Cancer Treat Rev 2012; 38: 767-775.

156 Karakas B, Bachman KE, Park BH. Mutation of the PIK3CA oncogene in human cancers. Br J Cancer 2006; 94: 455-459.

157 Russnes HG, Navin N, Hicks J, Borresen-Dale AL. Insight into the heterogeneity of breast cancer through next-generation sequencing. J Clin Invest 2011; 121: 3810-3818.

158 Bleeker FE, Felicioni L, Buttitta F, Lamba S, Cardone L, Rodolfo M et al. AKT1(E17K) in human solid tumours. Oncogene 2008; 27: 5648-5650.

159 Schmitz KJ, Otterbach F, Callies R, Levkau B, Holscher M, Hoffmann O et al. Prognostic relevance of activated Akt kinase in node-negative breast cancer: a clinicopathological study of 99 cases. Mod Pathol 2004; 17: 15-21.

160 Aleskandarany MA, Rakha EA, Ahmed MA, Powe DG, Ellis IO, Green AR. Clinicopathologic and molecular significance of phospho-Akt expression in early invasive breast cancer. Breast Cancer Res Treatment 2011; 127: 407-416.

161 Kirkegaard T, Witton CJ, McGlynn LM, Tovey SM, Dunne B, Lyon A et al. AKT activation predicts outcome in breast cancer patients treated with tamoxifen J Pathol 2005; 207: 139-146.

162 Wendel HG, de Stanchina E, Fridman JS, Malina A, Ray S, Kogan S et al. Surviva signalling by Akt and elF4E in oncogenesis and cancer therapy. Nature 2004; 428: 332-337.

163 Yunokawa M, Koizumi F, Kitamura Y, Katanasaka Y, Okamoto N, Kodaira M et al. Efficacy of everolimus, a novel mTOR inhibitor, against basal-like triple-negative breast cancer cells. Cancer Sci 2012; 103: 1665-1671.

164 Grunwald V, DeGraffenried L, Russel D, Friedrichs WE, Ray RB, Hidalgo M. Inhibitors of mTOR reverse doxorubicin resistance conferred by PTEN status in prostate cancer cells. Cancer Res 2002; 62: 6141-6145.

165 Zhang XB, Zhang S, Liu Y, Liu JJ, Ma Y, Zhu YX et al. Effects of the combination of RAD001 and docetaxel on breast cancer stem cells. Eur J Cancer 2012; 48. 1581-1592.

166 Xue YW, Chen J, Choi HH, Phan L, Chou PC, Zhao RY et al. HER2-Akt signaling in regulating COP9 signalsome subunit 6 and p53. Cell Cycle 2012; 11: 4181-4190.

167 Juvekar A, Burga LN, Hu H, Lunsford EP, Ibrahim YH, Balmana J et al. Combining a PI3K inhibitor with a PARP inhibitor provides an effective therapy for BRCA1related breast cancer. Cancer Discov 2012; 2: 1048-1063.

168 Shen WH, Balajee AS, Wang JL, Wu H, Eng C, Pandolfi PP et al. Essential role for nuclear PTEN in maintaining chromosomal integrity. Cell 2007; 128: 157-170.

169 Freeman DJ, Li AG, Wei G, Li HH, Kertesz N, Lesche $\mathrm{R}$ et al. PTEN tumor suppressor regulates $\mathrm{p} 53$ protein levels and activity through phosphatase-dependent and -independent mechanisms. Cancer Cell 2003; 3: 117-130.

170 Trotman LC, Pandolfi PP. PTEN and p53: Who will get the upper hand? Cancer Cell 2003; 3: 97-99.

171 Mayo LD, Donner DB. A phosphatidylinositol 3-kinase/Akt pathway promotes translocation of Mdm2 from the cytoplasm to the nucleus. Proc Natl Acad Sci USA 2001; 98: 11598-11603.

172 Ashcroft M, Ludwig RL, Woods DB, Copeland TD, Weber HO, MacRae EJ et al. Phosphorylation of HDM2 by Akt. Oncogene 2002; 21: 1955-1962.

173 Ogawara Y, Kishishita S, Obata T, Isazawa Y, Suzuki T, Tanaka K et al. Akt enhances Mdm2-mediated ubiquitination and degradation of p53. J Biol Chem 2002; 277: 21843-21850.
174 Gottlieb TM, Leal JFM, Seger R, Taya Y, Oren M. Cross-talk between Akt, p53 and Mdm2: possible implications for the regulation of apoptosis. Oncogene 2002; 21: 1299-1303.

175 Ali IU, Schriml LM, Dean M. Mutational spectra of PTEN/MMAC1 gene: a tumor suppressor with lipid phosphatase activity. J Natl Cancer Inst 1999; 91: 1922 1932.

176 Nagata Y, Lan KH, Zhou XY, Tan M, Esteva FJ, Sahin AA et al. PTEN activation contributes to tumor inhibition by trastuzumab, and loss of PTEN predicts trastuzumab resistance in patients. Cancer Cell 2004; 6: 117-127.

177 Perren A, Weng LP, Boag AH, Ziebold U, Thakore K, Dahia PLM et al. Immunohistochemical evidence of loss of PTEN expression in primary ductal adenocarcinomas of the breast. Am J Pathol 1999; 155: 1253-1260.

178 Depowski PL, Rosenthal SI, Ross JS. Loss of expression of the PTEN gene protein product is associated with poor outcome in breast cancer. Mod Pathol 2001; 14: 672-676.

179 Garcia JM, Silva J, Pena C, Garcia V, Rodriguez R, Cruz MA et al. Promoter methylation of the PTEN gene is a common molecular change in breast cancer. Genes Chromosomes Cancer 2004; 41: 117-124.

180 Zysman MA, Chapman WB, Bapat B. Considerations when analyzing the methylation status of PTEN tumor suppressor gene. Am J Pathol 2002; 160: 795-800.

181 Poliseno L, Salmena L, Zhang JW, Carver B, Haveman WJ, Pandolfi PP. A codingindependent function of gene and pseudogene mRNAs regulates tumour biology. Nature 2010; 465: 1033-U90.

182 Salmena L, Poliseno L, Tay Y, Kats L, Pandolfi PP. A ceRNA hypothesis: the rosetta stone of a hidden RNA language? Cell 2011; 146: 353-358.

183 Viktorsson K, De Petris L, Lewensohn R. The role of p53 in treatment responses of lung cancer. Biochem Biophys Res Commun 2005; 331: 868-880.

184 Lord CJ, Ashworth A. The DNA damage response and cancer therapy. Nature 2012; 481: 287-294.

185 Martin SA, Lord CJ, Ashworth A. DNA repair deficiency as a therapeutic target in cancer. Curr Opin Genet Dev 2008; 18: 80-86.

186 Zhang HB, Somasundaram K, Peng Y, Tian H, Zhang HX, Bi DK et al. BRCA1 physically associates with p53 and stimulates its transcriptional activity. Oncogene 1998; 16: 1713-1721.

187 Zurer I, Hofseth LJ, Cohen Y, Xu-Welliver M, Hussain SP, Harris CC et al. The role of p53 in base excision repair following genotoxic stress. Carcinogenesis 2004; 25: 11-19.

188 Chen JG, Sadowski I. Identification of the mismatch repair genes PMS2 and MLH1 as p53 target genes by using serial analysis of binding elements. Proc Nat Acad Sci USA 2005; 102: 4813-4818.

189 Bhana S, Hewer A, Phillips DH, Lloyd DR. p53-dependent global nucleotide excision repair of cisplatin-induced intrastrand cross links in human cells. Mutagenesis 2008; 23: 131-136.

190 Wang XW, Vermeulen W, Coursen JD, Gibson M, Lupold SE, Forrester K et al. The XPB and XPD DNA helicases are components of the p53-mediated apoptosis pathway. Genes Dev 1996; 10: 1219-1232.

191 Hwang BJ, Ford JM, Hanawalt PC, Chu G. Expression of the p48 xeroderma pigmentosum gene is $\mathrm{p53}$-dependent and is involved in global genomic repair. Proc Natl Acad Sci USA 1999; 96: 424-428.

192 Williams SA, Wilson JB, Clark AP, Mitson-Salazar A, Tomashevski A, Ananth S et al. Functional and physical interaction between the mismatch repair and FA-BRCA pathways. Hum Mol Genet 2011; 20: 4395-4410.

193 Romeo F, Falbo L, Di Sanzo M, Misaggi R, Faniello MC, Viglietto G et al. BRCA1 is required for hMLH1 stabilization following doxorubicin-induced DNA damage. Int J Biochem Cell Biol 2011; 43: 1754-1763.

194 Foray N, Marot D, Gabriel A, Randrianarison V, Carr AM, Perricaudet M et al. A subset of ATM- and ATR-dependent phosphorylation events requires the BRCA1 protein. EMBO J 2003; 22: 2860-2871.

195 Norgauer J, Idzko M, Panther E, Hellstern O, Herouy Y. Xeroderma pigmentosum Eur J Dermatol 2003; 13: 4-9.

196 Friedberg EC. How nucleotide excision repair protects against cancer. Nat Rev Cancer 2001; 1: 22-33.

197 Wang QE, Milum K, Han CH, Huang YW, Wani G, Thomale J et al. Differential contributory roles of nucleotide excision and homologous recombination repair for enhancing cisplatin sensitivity in human ovarian cancer cells. Mol Cancer 2011; 10.

198 Reardon JT, Vaisman A, Chaney SG, Sancar A. Efficient nucleotide excision repair of cisplatin, oxaliplatin, and bis-aceto-ammine-dichloro-cyclohexylamine-platinum(IV) (JM216) platinum intrastrand DNA diadducts. Cancer Res 1999; 59: 3968-3971.

199 Dabholkar M, Bostick-Bruton F, Weber C, Bohr VA, Egwuagu C, Reed E. ERCC1 and ERCC2 expression in malignant tissues from ovarian cancer patients. $J$ Natl Cancer Inst 1992; 84: 1512-1517. 
200 Metzger R, Leichman CG, Danenberg KD, Danenberg PV, Lenz HJ, Hayashi K et al. ERCC1 mRNA levels complement thymidylate synthase mRNA levels in predicting response and survival for gastric cancer patients receiving combination cisplatin and fluorouracil chemotherapy. J Clin Oncol 1998; 16: 309-316.

201 Park JS, Jeon EK, Chun SH, Won HS, Lee A, Hur SY et al. ERCC1 (excision repair cross-complementation group 1) expression as a predictor for response of neoadjuvant chemotherapy for FIGO stage $2 \mathrm{~B}$ uterine cervix cancer. Gynecol Oncol 2011; 120: 275-279.

202 Tsai CM, Chang KT, Li L, Perng RP, Yang LY. Interrelationships between cellular nucleotide excision repair, cisplatin cytotoxicity, HER-2/neu gene expression, and epidermal growth factor receptor level in non-small cell lung cancer cells. Jpn J Cancer Res 2000; 91: 213-222.

203 Hsu DSS, Lan HY, Huang CH, Tai SK, Chang SY, Tsai TL et al. Regulation of excision repair cross-complementation group 1 by snail contributes to cisplatin resistance in head and neck cancer. Clin Cancer Res 2010; 16 : 4561-4571.

204 Zhou W, Gurubhagavatula S, Liu G, Park S, Neuberg DS, Wain JC et al. Excision repair cross-complementation group 1 polymorphism predicts overall survival in advanced non-small cell lung cancer patients treated with platinum-based chemotherapy. Clin Cancer Res 2004; 10: 4939-4943.

205 Park DJ, Stoehlmacher J, Zhang W, Tsao-Wei DD, Groshen S, Lenz HJ. A. Xeroderma pigmentosum group $\mathrm{D}$ gene polymorphism predicts clinical outcome to platinum-based chemotherapy in patients with advanced colorectal cancer. Cancer Res 2001; 61: 8654-8658.

206 Santonocito C, Scapaticci M, Penitente R, Paradisi A, Capizzi R, Lanza-Silveri S et al. Polymorphisms in base excision DNA repair genes and association with melanoma risk in a pilot study on Central-South Italian population. Clin Chim Acta 2012; 413: 1519-1524.

207 Yang J, Parsons J, Nicolay NH, Caporali S, Harrington CF, Singh R et al. Cells deficient in the base excision repair protein, DNA polymerase beta, are hypersensitive to oxaliplatin chemotherapy. Oncogene 2010; 29: 463-468.

208 van der Kolk DM, de Bock GH, Leegte BK, Schaapveld M, MJE Mourits, de Vries J et al. Penetrance of breast cancer, ovarian cancer and contralateral breast cancer in BRCA1 and BRCA2 families: high cancer incidence at older age. Breast Cancer Res Treat 2010; 124: 643-651.

209 Evans DG, Shenton A, Woodward E, Lalloo F, Howell A, Maher ER. Penetrance estimates for BRCA1 and BRCA2 based on genetic testing in a Clinical Cancer Genetics service setting: risks of breast/ovarian cancer quoted should reflect the cancer burden in the family. BMC Cancer 2008; 8: 155.

210 Rafnar T, Gudbjartsson DF, Sulem P, Jonasdottir A, Sigurdsson A, Besenbacher S et al. Mutations in BRIP1 confer high risk of ovarian cancer. Nat Genet 2011; 43: 1104-U91.

211 Rahman N, Seal S, Thompson D, Kelly P, Renwick A, Elliott A et al. PALB2, which encodes a BRCA2-interacting protein, is a breast cancer susceptibility gene. Nat Genet 2007; 39: 165-167.

212 Somyajit K, Subramanya S, Nagaraju G. Distinct roles of Fanco/RAD51C protein in DNA damage signaling and repair implications for fanconi anemia and breast cancer susceptibility. J Biol Chem 2012; 287: 3366-3380.

213 Walsh T, Casadei S, Lee MK, Pennil CC, Nord AS, Thornton AM et al. Mutations in 12 genes for inherited ovarian, fallopian tube, and peritoneal carcinoma identified by massively parallel sequencing. Proc Natl Acad Sci USA 2011; 108: 18032-18037.

214 Loveday C, Turnbull C, Ramsay E, Hughes D, Ruark E, Frankum JR et al. Germline mutations in RAD51D confer susceptibility to ovarian cancer. Nat Genet 2011; 43 : 879-U90.

215 Meindl A, Hellebrand H, Wiek C, Erven V, Wappenschmidt B, Niederacher D et al. Germline mutations in breast and ovarian cancer pedigrees establish RAD51C as a human cancer susceptibility gene. Nat Genet 2010; 42: 410-U65.

216 Valeri A, Martinez S, Casado JA, Bueren JA. Fanconi anaemia: from a monogenic disease to sporadic cancer. Clin Transl Oncol 2011; 13: 215-221.

217 Garcia MJ, Benitez J. The Fanconi anaemia/BRCA pathway and cancer susceptibility: searching for new therapeutic targets. Clin Transl Oncol 2008; 10(2): 7884.

218 Cheang MCU, Voduc D, Bajdik C, Leung S, McKinney S, Chia SK et al. Basal-like breast cancer defined by five biomarkers has superior prognostic value then triple-negative phenotype. Clin Cancer Res 2008; 14: 1368-1376.

219 Rakha EA, Elsheikh SE, Aleskandarany MA, Habashi HO, Green AR, Powe DG et al. Triple-negative breast cancer: distinguishing between basal and nonbasal subtypes. Clin Cancer Res 2009; 15: 2302-2310.

220 Liedtke C, Mazouni C, Hess KR, Andre F, Tordai A, Mejia JA et al. Response to neoadjuvant therapy and long-term survival in patients with triple-negative breast cancer. J Clin Oncol 2008; 26: 1275-1281.

221 Carey LA, Dees EC, Sawyer L, Gatti L, Moore DT, Collichio F et al. The triple negative paradox: primary tumor chemosensitivity of breast cancer subtypes. Clin Cancer Res 2007; 13: 2329-2334.
222 Rouzier R, Perou CM, Symmans WF, Ibrahim N, Cristofanilli M, Anderson K et al. Breast cancer molecular subtypes respond differently to preoperative chemotherapy. Clin Cancer Res 2005; 11: 5678-5685.

223 Silver DP, Richardson AL, Eklund AC, Wang ZC, Szallasi Z, Li Q et al. Efficacy of neoadjuvant cisplatin in triple-negative breast cancer. J Clin Oncol 2010; 28: $1145-1153$.

224 Sirohi B, Arnedos M, Popat S, Ashley S, Nerurkar A, Walsh G et al. Platinum-based chemotherapy in triple-negative breast cancer. Ann Oncol 2008; 19: 1847-1852.

225 Young SR, Pilarski RT, Donenberg T, Shapiro C, Hammond LS, Miller J et al. The prevalence of BRCA1 mutations among young women with triple-negative breast cancer. BMC Cancer 2009; 9: 86.

226 Arun B, Bayraktar S, Liu DD, Barrera AMG, Atchley D, Pusztai L et al. Response to neoadjuvant systemic therapy for breast cancer in BRCA mutation carriers and noncarriers: a single-institution experience. J Clin Oncol 2011; 29: 3739-3746.

227 Kriege M, Seynaeve C, Meijers-Heijboer H, Collee JM, Menke-Pluymers MBE, Bartels CCM et al. Sensitivity to first-line chemotherapy for metastatic breast cancer in BRCA1 and BRCA2 mutation carriers. J Clin Oncol 2009; 27: 3764-3771.

228 Bayraktar S, Gutierrez-Barrera AM, Liu D, Tasbas T, Akar U, Litton JK et al. Outcome of triple-negative breast cancer in patients with or without deleterious BRCA mutations. Breast Cancer Res Treat 2011; 130: 145-153.

229 Byrski T, Gronwald J, Huzarski T, Grzybowska E, Budryk M, Stawicka M et al. Pathologic complete response rates in young women with BRCA1-positive breast cancers after neoadjuvant chemotherapy. J Clin Oncol 2010; 28: 375-379.

230 Gronwald J, Byrski T, Huzarski T, Dent R, Bielicka V, Zuziak D et al. Neoadjuvant therapy with cisplatin in BRCA1-positive breast cancer patients. J Clin Oncol 2009; 27(Suppl 155): 7.

231 Kriege M, Jager A, Hooning MJ, Huijskens E, Blom J, van Deurzen CHM et al. The efficacy of taxane chemotherapy for metastatic breast cancer in BRCA1 and BRCA2 mutation carriers. Cancer 2012; 118: 899-907.

232 Chabalier C, Lamare C, Racca C, Privat M, Valette A, Larminat F. BRCA1 downregulation leads to premature inactivation of spindle checkpoint and confers paclitaxel resistance. Cell Cycle 2006; 5: 1001-1007.

233 Alsop K, Fereday S, Meldrum C, deFazio A, Emmanuel C, George J et al. BRCA mutation frequency and patterns of treatment response in BRCA mutationpositive women with ovarian cancer: a report from the Australian Ovarian Cancer Study Group. J Clin Oncol 2012; 30: 2654-2663.

234 Eisenhauer EA, Vermorken JB, vanGlabbeke M. Predictors of response to subsequent chemotherapy in platinum pretreated ovarian cancer: a multivariate analysis of 704 patients. Ann Oncol 1997; 8: 963-968.

235 Tan DSP, Rothermundt C, Thomas K, Bancroft E, Eeles R, Shanley S et al. 'BRCAness' syndrome in ovarian cancer: a case-control study describing the clinical features and outcome of patients with epithelial ovarian cancer associated with BRCA1 and BRCA2 mutations. J Clin Oncol 2008; 26: 5530-5536.

236 Vencken $\mathrm{P}$, Kriege M, Hoogwerf D, Beugelink S, van der Burg MEL, Hooning MJ et al. Chemosensitivity and outcome of BRCA1- and BRCA2-associated ovarian cancer patients after first-line chemotherapy compared with sporadic ovarian cancer patients. Ann Oncol 2011; 22: 1346-1352.

237 Dann RB, DeLoia JA, Timms KM, Zorn KK, Potter J, Flake DD et al. BRCA1/2 mutations and expression: response to platinum chemotherapy in patients with advanced stage epithelial ovarian cancer. Gynecol Oncol 2012; 125: 677-682.

238 Yang D, Khan S, Sun Y, Hess K, Shmulevich I, Sood AK et al. Association of BRCA1 and BRCA2 mutations with survival, chemotherapy sensitivity, and gene mutator phenotype in patients with ovarian cancer. J Am Med Assoc 2011; 306: 1557-1565.

239 Edwards SL, Brough R, Lord CJ, Natrajan R, Vatcheva R, Levine DA et al. Resistance to therapy caused by intragenic deletion in BRCA2. Nature 2008; 451: 1111-1115.

240 Sakai W, Swisher EM, Karlan BY, Agarwal MK, Higgins J, Friedman C et al. Secondary mutations as a mechanism of cisplatin resistance in BRCA2-mutated cancers. Nature 2008; 451: 1116-U9.

241 Norquist B, Wurz KA, Pennil CC, Garcia R, Gross J, Sakai W et al. Secondary somatic mutations restoring BRCA1/2 predict chemotherapy resistance in hereditary ovarian carcinomas. J Clin Oncol 2011; 29: 3008-3015.

242 Swisher EM, Sakai W, Karlan BY, Wurz K, Urban N, Taniguchi T. Secondary BRCA1 mutations in BRCA1-mutated ovarian carcinomas with platinum resistance. Cancer Res 2008; 68: 2581-2586.

243 Smiraldo PG, Gruver AM, Osborn JC, Pittman DL. Extensive chromosomal instability in Rad51d-deficient mouse cells. Cancer Res 2005; 65: 2089-2096.

244 Hartwell LH, Szankasi P, Roberts CJ, Murray AW, Friend SH. Integrating genetic approaches into the discovery of anticancer drugs. Science 1997; 278: 1064-1068.

245 Farmer H, McCabe N, Lord CJ, Tutt ANJ, Johnson DA, Richardson TB et al. Targeting the DNA repair defect in BRCA mutant cells as a therapeutic strategy. Nature 2005; 434: 917-921. 
246 Bryant HE, Schultz N, Thomas HD, Parker KM, Flower D, Lopez E et al. Specific killing of BRCA2-deficient tumours with inhibitors of poly(ADP-ribose) polymerase. Nature 2005; 434: 913-917.

247 Rehman FL, Lord CJ, Ashworth A. Synthetic lethal approaches to breast cancer therapy. Nat Rev Clin Oncol 2010; 7: 718-724.

248 Dworkin AM, Spearman AD, Tseng SY, Sweet K, Toland AE. Methylation not a frequent 'second hit' in tumors with germline BRCA mutations. Fam Cancer 2009; 8: $339-346$.

249 Fong PC, Boss DS, Yap TA, Tutt A, Wu P, Mergui-Roelvink M et al. Inhibition of poly(ADP-ribose) polymerase in tumors from BRCA mutation carriers. $N$ Engl J Med 2009; 361: 123-134.

250 Fong PC, Yap TA, Boss DS, Carden CP, Mergui-Roelvink M, Gourley C et al. Poly(ADP)-ribose polymerase inhibition: frequent durable responses in BRCA carrier ovarian cancer correlating with platinum-free interval. J Clin Oncol 2010; 28: 2512-2519.

251 Audeh MW, Carmichael J, Penson RT, Friedlander M, Powell B, Bell-McGuinn KM et al. Oral poly(ADP-ribose) polymerase inhibitor olaparib in patients with BRCA1 or BRCA2 mutations and recurrent ovarian cancer: a proof-of-concept trial. Lancet 2010; 376: 245-251.

252 Tutt A, Robson M, Garber JE, Domchek SM, Audeh MW, Weitzel JN et al. Oral poly(ADP-ribose) polymerase inhibitor olaparib in patients with BRCA1 or BRCA2 mutations and advanced breast cancer: a proof-of-concept trial. Lancet 2010; 376: 235-244.

253 Gelmon KA, Tischkowitz M, Mackay H, Swenerton K, Robidoux A, Tonkin K et al. Olaparib in patients with recurrent high-grade serous or poorly differentiated ovarian carcinoma or triple-negative breast cancer: a phase 2, multicentre, openlabel, non-randomised study. Lancet Oncol 2011; 12: 852-861.

254 Ledermann J, Harter P, Gourley C, Friedlander M, Vergote I, Rustin G et al. Olaparib maintenance therapy in platinum-sensitive relapsed ovarian cancer. N Engl J Med 2012; 366: 1382-1392.

255 Hennessy BTJ, Timms KM, Carey MS, Gutin A, Meyer LA, Flake II DD et al. Somatic mutations in BRCA1 and BRCA2 could expand the number of patients that benefit from poly (ADP Ribose) polymerase inhibitors in ovarian cancer. J Clin Oncol 2010; 28: 3570-3576.

256 Bell D, Berchuck A, Birrer M, Chien J, Cramer DW, Dao F et al. Integrated genomic analyses of ovarian carcinoma. Nature 2011; 474: 609-615.

257 Moskwa P, Buffa FM, Pan YF, Panchakshari R, Gottipati P, Muschel RJ et al. miR182-mediated downregulation of BRCA1 impacts DNA repair and sensitivity to PARP inhibitors. Mol Cell 2011; 41: 210-220.

258 Garcia Al, Buisson M, Bertrand P, Rimokh R, Rouleau E, Lopez BS et al. Downregulation of $B R C A 1$ expression by miR-146a and miR-146b-5p in triple negative sporadic breast cancers. EMBO Mol Med 2011; 3: 279-290.

259 Villarroel MC, Rajeshkumar NV, Garrido-Laguna I, De Jesus-Acosta A, Jones S, Maitra $A$ et al. Personalizing cancer treatment in the age of global genomic analyses: PALB2 gene mutations and the response to DNA damaging agents in pancreatic cancer. Mol Cancer Ther 2011; 10: 3-8.

260 Hastak K, Alli E, Ford J. Synergistic chemosensitivity of triple-negative breast cancer cell lines to poly(ADP-Ribose) polymerase inhibition, gemcitabine and cisplatin. Cancer Res 2010; 70: 7970-7980.

261 O'Shaughnessy J, Osborne C, Pippen JE, Yoffe M, Patt D, Rocha C et al. Iniparib plus chemotherapy in metastatic triple-negative breast cancer. $N$ Engl J Med 2011; 364: 205-214.

262 O'Shaugnessy J. A randomized phase III study of iniparib (BSI-201) in combination with gemcitabine/carboplatin $(\mathrm{G} / \mathrm{C})$ in metastatic triple-negative brerast cancer (TNBC). J Clin Oncol (Suppl) 2011; 29: 15S-18S

263 Patel AG, De Lorenzo SB, Flatten KS, Poirier GG, Kaufmann SH. Failure of iniparib to inhibit poly(ADP-Ribose) polymerase in vitro. Clin Cancer Res 2012; 18: 1655-1662.

264 Dedes KJ, Wilkerson PM, Wetterskog D, Weigelt B, Ashworth A, Reis-Filho JS. Synthetic lethality of PARP inhibition in cancers lacking BRCA1 and BRCA2 mutations. Cell Cycle 2011; 10: 1192-1199.

265 Liu XS, Han EK, Anderson M, Shi Y, Semizarov D, Wang G et al. Acquired resistance to combination treatment with temozolomide and ABT-888 Is mediated by both base excision repair and homologous recombination DNA repair pathways. Mol Cancer Res 2009; 7: 1686-1692.

266 Domagala P, Huzarski T, Lubinski J, Gugala K, Domagala W. PARP-1 expression in breast cancer including BRCA1-associated, triple negative and basal-like tumors: possible implications for PARP-1 inhibitor therapy. Breast Cancer Res Treat 2011; 127: $861-869$.
267 von Minckwitz G, Muller BM, Loibl S, Budczies J, Hanusch C, Darb-Esfahani S et al. Cytoplasmic poly(adenosine diphosphate-ribose) polymerase expression is predictive and prognostic in patients with breast cancer treated with neoadjuvant chemotherapy. J Clin Oncol 2011; 29: 2150-2157.

268 Kerzendorfer C, O'Driscoll M. Human DNA damage response and repair deficiency syndromes: linking genomic instability and cell cycle checkpoint proficiency. DNA Repair 2009; 8: 1139-1152.

$269 \mathrm{Fu}$ YP, Yu JC, Cheng TC, Lou MA, Hsu GC, Wu CY et al. Breast cancer risk associated with genotypic polymorphism of the nonhomologous end-joining genes: a multigenic study on cancer susceptibility. Cancer Res 2003; 63: 2440-2446.

270 Merel P, Prieur A, Pfeiffer P, Delattre O. Absence of major defects in nonhomologous DNA end joining in human breast cancer cell lines. Oncogene 2002; 21: $5654-5659$.

271 Lynch HT, Lynch PM, Lanspa SJ, Snyder CL, Lynch JF, Boland CR. Review of the Lynch syndrome: history, molecular genetics, screening, differential diagnosis, and medicolegal ramifications. Clin Genet 2009; 76: 1-18.

272 Ribic CM, Sargent DJ, Moore MJ, Thibodeau SN, French AJ, Goldberg RM et al. Tumor microsatellite-instability status as a predictor of benefit from fluorouracilbased adjuvant chemotherapy for colon cancer. N Engl J Med 2003; 349: 247-257.

273 Vasen $\mathrm{H}$, Watson PH, Mecklin J-P, Lynch H. New clinical criteria for hereditary nonpolyposis colorectal cancer (HNPCC Lynch syndrome) proposed by the International Collaborative Group on HNPCC. Gastroenterology 1999; 116: 1453-1456.

274 Honecker F, Wermann H, Mayer F, Gillis AJM, Stoop H, van Gurp R et al. Microsatellite instability, mismatch repair deficiency, and BRAF mutation in treatment-resistant germ cell tumors. J Clin Oncol 2009; 27: 2129-2136.

275 Martin SA, McCarthy A, Barber LJ, Burgess DJ, Parry S, Lord CJ et al. Methotrexate induces oxidative DNA damage and is selectively lethal to tumour cells with defects in the DNA mismatch repair gene MSH2. EMBO Mol Med 2009; 1 323-337.

276 Diouf B, Cheng Q, Krynetskaia NF, Yang WJ, Cheok M, Pei DQ et al. Somatic deletions of genes regulating MSH2 protein stability cause DNA mismatch repair deficiency and drug resistance in human leukemia cells. Nat Med 2011; 17: 1298-U332.

277 Kaina B, Christmann M, Naumann S, Roos WP. MGMT: key node in the battle against genotoxicity, carcinogenicity and apoptosis induced by alkylating agents. DNA Repair 2007; 6: 1079-1099.

278 Paz MF, Yaya-Tur R, Rojas-Marcos I, Reynes G, Pollan M, Aguirre-Cruz L et al. CpG island hypermethylation of the DNA repair enzyme methyltransferase predicts response to temozolomide in primary gliomas. Clin Cancer Res 2004; 10 4933-4938.

279 Balana C, Ramirez JL, Taron M, Roussos $\mathrm{Y}$, Ariza A, Ballester $\mathrm{R}$ et al. O6-methyl-guanine-DNA methyltransferase methylation in serum and tumor DNA predicts response to 1,3-bis(2-chloroethyl)-1-nitrosourea but not to temozolamide plus cisplatin in glioblastoma multiforme. Clin Cancer Res 2003; 9 1461-1468.

280 Hegi ME, Diserens A, Gorlia T, Hamou M, de Tribolet N, Weller M et al. MGMT gene silencing and benefit from temozolomide in glioblastoma. $N$ Engl J Med 2005; 352: 997-1003.

281 Sjøblom T, Jones S, Wood LD, Parsons DW, Lin J, Barber TD et al. The consensus coding sequences of human breast and colorectal cancers. Science 2006; 314: 268-274.

282 Greenman C, Stephens P, Smith R, Dalgliesh GL, Hunter C, Bignell G et al. Patterns of somatic mutation in human cancer genomes. Nature 2007; 446: 153-158.

283 Castillo P, Bogliolo M, Surralles J. Coordinated action of the Fanconi anemia and ataxia telangiectasia pathways in response to oxidative damage. DNA Repair 2011; 10: 518-525.

284 Ibrahim YH, Garcia-Garcia C, Serra V, He L, Torres_Lockhart K, Prat A et al. PI3K inhibition impairs BRCA1/2 expression and sensitizes BRCA-proficient triplenegative breast cancer to PARP-inhibition. Cancer Discovery 2012; 2: 1036-1047.

This work is licensed under a Creative Commons Attribution 3.0 Unported License. To view a copy of this license, visit http:// ns.org/licenses/by/3.0/ 